\title{
THE BRIGHT SIDE OF CORPORATE DIVERSIFICATION: EVIDENCE FROM INTERNAL LABOR MARKETS
}

\author{
by \\ Geoffrey Tate \\ University of North Carolina \\ Liu Yang \\ University of Maryland
}

\begin{abstract}
CES 13-40
August, 2013

The research program of the Center for Economic Studies (CES) produces a wide range of economic analyses to improve the statistical programs of the U.S. Census Bureau. Many of these analyses take the form of CES research papers. The papers have not undergone the review accorded Census Bureau publications and no endorsement should be inferred. Any opinions and conclusions expressed herein are those of the author(s) and do not necessarily represent the views of the U.S. Census Bureau. All results have been reviewed to ensure that no confidential information is disclosed. Republication in whole or part must be cleared with the authors.

To obtain information about the series, see www.census.gov/ces or contact Fariha Kamal, Editor, Discussion Papers, U.S. Census Bureau, Center for Economic Studies 2K132B, 4600 Silver Hill Road, Washington, DC 20233, CES.Papers.List@census.gov.
\end{abstract}




\begin{abstract}
We estimate the labor market consequences of corporate diversification using worker-firm matched data from the U.S. Census Bureau. We find evidence that workers in diversified firms have greater cross-industry mobility. Displaced workers experience significantly smaller losses when they move to a firm in a new industry in which their former firm also operates. We also find more active internal labor markets in diversified firms. Diversified firms exploit the option to redeploy workers internally from declining to expanding industries. Though diversified firms pay higher wages to retain workers, their labor is also more productive than focused firms of the same size, age, and industry. Overall, internal labor markets provide a bright side to corporate diversification.
\end{abstract}

\footnotetext{
We thank Ashwini Agrawal, Miguel Ferreira, Vojislav Maksimovic, Julie Wulf, and seminar participants at Columbia Graduate School of Business, Harvard Business School, University of Maryland, MIT, University of North Carolina, Northwestern University, University of Oregon, Purdue University, UBC, UCLA, USC, the 2012 Annual Meeting of the American Finance Association, the 2012 NBER Corporate Finance Program Meeting and the Fourth Paris Spring Corporate Finance Conference for helpful comments. We acknowledge financial support from the Fink Center for Finance and Investments, the Richard S. Ziman Center for Real Estate, and the Institute for Research on Labor and Employment. The research in this paper was conducted while the authors were Special Sworn Status researchers of the U.S. Census Bureau. This research uses data from the Census Bureau's Longitudinal Employer Household Dynamics Program, which was partially supported by the following National Science Foundation Grants SES9978093, SES-0339191 and ITR-0427889; National Institute on Aging Grant AG018854; and grants from the Alfred P. Sloan Foundation. Any opinions and conclusions expressed herein are those of the authors and do not necessarily represent the views of the U.S. Census Bureau. All results have been reviewed to ensure that no confidential information is disclosed. Contact information: lyang@rhsmith.umd.edu.
} 
The boundaryless company we envision will remove the barriers among engineering, manufacturing, marketing, sales, and customer service; it will recognize no distinctions between domestic and foreign operations... A boundaryless organization will ignore or erase group labels... which get in the way of people working together.

- Jack Welch, CEO, GE 1989 Annual Report

What are the benefits of corporate diversification? Traditional finance theory argues that broader internal capital markets can help diversified firms to overcome frictions in the external capital market. Yet, the empirical evidence on the efficiency of internal capital allocation in conglomerates is mixed. ${ }^{1}$ Using novel worker-level data, we observe active internal labor markets in diversified firms: internal job changes occur more frequently than in focused firms and often involve crossindustry moves. Thus, we propose that diversification improves productivity by enabling firms to develop and deploy human capital more effectively.

Since diversified firms operate in multiple industries, a potential source of synergies is the ability to develop and deploy workers whose skill sets span multiple tasks or industries. A lawyer in a diversified firm might litigate cases for the firm's finance and health care divisions, developing expertise and experience in both areas of the law. An engineer may develop technologies for units of the conglomerate which produce aircraft engines and home appliances. Workers may participate in joint ventures of different business segments. Or, promising young employees may take advantage of internal job rotation programs to acquire the broad organizational knowledge necessary to climb the corporate hierarchy. These opportunities, which are less common in focused firms, increase the scope and quality of workers' outside opportunities. In return, they create value for the firm by generating opportunities for innovation and the seamless transfer of "best practices" across the organization. For example, Jack Welch initiated the well-known "Work-Out" program at GE in the 1990s with the goal of cultivating such synergies through "integrated diversity."

\footnotetext{
${ }^{1}$ See Stein (2003) and Maksimovic and Phillips (2007) for surveys of the extensive literature on internal capital markets and diversification.
} 
Moreover, an internal stock of generalist workers enables the firm to respond more effectively to industry shocks, redeploying workers - and not just physical capital - to lines of business with the best opportunities. This option is particularly valuable when shocks create mismatches between employer needs and worker skills in the external labor market.

We construct a worker-plant matched panel dataset to test several implications of this hypothesis. Our worker-firm matched data comes from the U.S. Census Bureau's Longitudinal Employer Household Dynamics (LEHD) program. The newly developed LEHD data covers a broad crosssection of the U.S. economy and includes $96 \%$ of the workers from covered states. ${ }^{2}$ We use the Census Bureau's Longitudinal Business Database (LBD) to identify the organizational structure within a firm and to measure diversification.

We begin by testing worker-level implications of our hypothesis. First, we test whether workers from diversified firms develop skills that allow them to move between the industries in which the diversified firm operates. We use wage changes following job turnover to measure workers' outside options. A key identification concern is the endogeneity of the choice to change jobs. ${ }^{3}$ Voluntary and involuntary job changes have different implications for wages and the rates of voluntary versus forced job changes may differ across diversified and focused firms for reasons other than differences in worker skills or opportunities. To avoid these confounds, we adapt the approach of Gibbons and Katz (1991), constructing a sample of worker-plant matched data that includes only involuntary job changes due to plant closures. We find that workers from diversified firms who change industries (and firms), but move to a new industry in which their former firm operates experience significantly smaller wage losses than other workers who switch between the same two industries.

Our result is robust to including a variety of individual-, plant-, and firm-level controls, including

\footnotetext{
${ }^{2}$ Although the LEHD program covers 48 states in the U.S., only information from 23 states is available through the Census Research Data Center (RDC).

${ }^{3}$ Note that we also consider the cross-section of organizational structure even though the structure of the firm is itself endogenous. Most diversified firms are large and mature. Since the decision to diversify typically occured well in the past, it is unlikely to be influenced by current worker skills.
} 
measures of local job opportunities and the distance between the old and new employers. Our results do not appear to be driven by sorting of better workers into diversified firms: displaced workers from diversified firms do not do better than their focused counterparts when they move to an industry that was not spanned by their previous firm or when they change firms in the same industry. Moreover, our result is not driven by sorting of better diversified workers into the industries in which the firm operates: within the group of workers making the switch between a pair of industries, we do not observe significant differences in observables (including ex ante wages) between workers from diversified firms that operate in the new industry and those that do not. We also confirm that the results are not driven by workers with experience in their post-displacement industries prior to entering the diversified firm and that the effects increase with the worker's tenure in the diversified firm. Finally, the differences in outcomes persist for (at least) three years following plant closure.

Next, we test for differences in the effect of skills attained inside the diversified firm depending on workers' skill levels. First, we use workers' ex ante wages as a proxy for skill, partitioning the sample into quartiles. For workers in the lowest wage group, the wage changes for industry switchers are the same regardless of whether the former employer operates in the new industry. However, as wage levels increase, the impact of exposure to the new industry in the old job increases monotonically. Second, we classify industries as high- or low-skill using the percentage of workers in high-skilled occupations (or Standard Occupational Classification (SOC) codes) in the 2-digit SIC. We find that the importance of exposure to the new industry at the former firm is distinct to industries that employ high-skilled labor. Thus, the development of general skills in diversified firms appears to carry more of a premium among high-skill workers, whose skills are likely to be scarce in the marketplace and among whom human capital is a key driver of productivity.

Having established the heightened flexibility of human capital in diversified firms at the worker level, we turn to the firm-level predictions of our hypothesis. First, we test whether diversified firms adjust their labor supplies differently from focused firms in response to changing industry 
opportunities. We continue to examine workers displaced by plant closure since it allows us to isolate firm-motivated labor retention and reallocation decisions. Because individual workers have a choice to accept an offer to remain inside the firm or to seek a job outside the firm, our estimates provide a lower bound on the firm's desired amount of internal labor reallocation. We estimate a two stage Heckman selection model: in the first stage, we model the diversified firm's choice to retain workers inside the firm and, in the second stage, we model the choice to reallocate workers to a different industry (conditional on retaining them). We find that diversified firms retain more workers when growth opportunities in their remaining industries are high; and, they are more likely to redeploy workers to different industries when growth opportunities in their former industries are declining. Moreover, the rate of reallocation across industries in diversified firms is higher than the rate of reallocation between the same industries in the open market.

Next, we provide more direct evidence on the benefits and costs of these differences in human capital to the firm. First, we confirm in a random sample that diversified firms pay higher wages than focused firms, consistent with the workers' higher outside options. However, we find that labor productivity (measured by the ratio of sales to payroll or sales to employment) is also significantly higher among diversified firms than among focused firms of the same size and age operating in the same industries. Thus, diversified firms appear to get more "bang for their buck."

We also link our evidence to the "diversification discount" in equity markets. Though diversified firms generate higher cash flows because of their enhanced ability to develop and deploy human capital, their human capital also carries greater risk due to enhanced external mobility. Workers can transfer part of the developed human capital to a different firm. Thus, for a given level of cash flows, diversified firms should have lower market valuations and the effect should be stronger for firms with more high-skill workers. Consistent with this conjecture, we find a significantly higher discount among firms that operate in high-skill industries. This interpretation is also consistent with existing evidence that the change in excess value over time (or, realized returns) is higher among diversified firms (Hund, Monk, and Tice (2010)). Moreover, since worker mobility is 
heightened during expansions (Jovanovic and Moffitt (1990)), it is consistent with recent evidence suggesting a narrowing of the discount during recessions (Kuppuswamy and Villalonga (2010)).

Our analysis provides a new angle on the benefits of corporate diversification. Workers in diversified firms develop general skills. These skills allow diversified firms to reallocate workers in the internal labor market in response to industry shocks, enhancing productivity. The desire to create these markets, then, may be an important determinant of the boundaries of the firm (Hart (1995)).

Our results also suggest a mechanism to reconcile a number of seemingly conflicting results from the existing literature on conglomerates. Schoar (2002) finds that the manufacturing plants of diversified firms have higher total factor productivity than the plants of focused firms in the cross-section. Moreover, Maksimovic and Phillips (2002) show that diversified firms achieve higher sales growth and adjust more easily to business cycles, particularly within core industries. Yet, other studies find less sensitivity of capital expenditures to industry Q among the business segments of diversified firms and argue that firms engage in "socialist" cross-subsidization of weak divisions at the expense of those with good opportunities (Ozbas and Scharfstein (2010); Lamont (1997); Rajan, Servaes and Zingales (2000)). Moreover, Lang and Stulz (1994), among others, argue that diversified firms trade at a discount relative to a portfolio of focused firms in the same lines of business.

We identify human capital investment as an important driver of increased productivity inside diversified firms. Unlike focused firms, diversified firms are able to redeploy labor internally in response to changing industry conditions. If labor and capital are partial substitutes and focused firms have less ability to adjust labor due to frictions in the external labor market, then we would expect to see a smaller elasticity of capital expenditures with respect to $\mathrm{Q}$ among diversified firms. Moreover, recent work in asset pricing identifies worker mobility as an important source of risk (Eisfeldt and Papanikolaou (forthcoming); Donangelo (2011)). Firms that invest more in organization capital carry an additional risk premium since key talent can transfer a fraction of 
that capital to a new firm and therefore demand wages that match their outside options. We show that diversified firms develop workers with general skills - increasing their value in the external labor market - and as a result pay higher wages. Thus, diversified firms may carry an additional risk premium, providing a way to reconcile the observed discount in equity markets with higher plant-level productivity. Our results suggest caution in interpreting the diversification discount as evidence of inefficient decision-making within conglomerates: diversified and focused firms are fundamentally different in terms of risk and, therefore, the cash flow-value relationship among focused firms does not provide an appropriate benchmark for valuing a segment of a diversified firm. ${ }^{4}$

The remainder of the paper is organized as follows. In Section I, we develop the testable implications of worker skill differences across diversified and focused firms. In Section II, we describe the data we use in our analysis and, in particular, the process by which we merge data across different Census products. In Section III, we measure the relation between worker skills, organizational structure, and cross-industry mobility. In Section IV, we link the presence of mobile skilled labor to cash flows and the diversification discount. Finally, in Section V, we conclude.

\section{Empirical Framework}

We propose that diversified and focused firms differ in how they deploy and invest in human capital. To guide our empirical tests, we outline the differences in equilibrium employment decisions and wages across the two types of firms using a competitive assignment framework. Our approach builds on the model proposed by Lazear (2009).

For simplicity, suppose that workers are endowed with an initial set of skills and are randomly assigned to an initial employer. Firms differ in the production function that maps employee skills

\footnotetext{
${ }^{4}$ Graham, Lemmon, and Wolf (1998), Campa and Kedia (1999), and Villalonga (2000) dispute the evidence of a "diversification dicount." Our story does not require that diversified firms trade at a discount - the increment to cash flows from heightened labor productivity can dominate the effect of a higher discount rate on stock prices. However, it is also consistent with an observed discount.
} 
to output and hence put unique weights on each distinct skill. Since these weights are idiosyncratic, it is difficult, in general, for the firm to find workers with the optimal mix of skills in the external labor market. After joining the firm, employees can invest in improving their human capital. Because workers' productivity in the firm depends on the quality of the match between their bundle of skills and the firm's needs, these investments favor the skills on which the firm places high weights. The resulting human capital therefore has a firm-specific component.

Individual skills themselves, however, are general and can enhance the worker's productivity both inside and outside the firm. Following investment, workers may receive offers from other firms. Because the developed human capital has a firm-specific component, in expectation the marginal productivity of labor is highest from the current match. The worker and firm, then, form a bilateral monopoly on this capital and wages are set through a bargaining process by which the worker and firm split the surplus created by the current match over the worker's outside option.

Diversified firms, by definition, operate broader lines of business than focused firms, spanning multiple industries. These different industries, in turn, are likely to utilize different sets of skills. Thus, we assume that diversified firms place non-zero skill-weights on a larger subset of the skills available in the labor market. Then, investments in human capital for workers in diversified firms will be more balanced than investments made by workers in focused firms. This difference in skill sets has important implications for workers experiencing involuntary job changes (e.g., due to plant closure). Workers in diversified firms develop skills used in a wider array of industries. Thus, they can find new employment within that set of industries with only modest wage losses. This includes their home industries as well as other industries in which their previous firms operate. Workers in focused firms, on the other hand, invest heavily in a set of skills that are industry-specific. Thus, they experience larger wage losses when they find new jobs outside of their home industries.

Hypothesis 1. Industry changes are less costly for workers from diversified firms who move to industries in which the diversified firm operates (or, "related" industries). 
More generally, ex ante matching of workers with broader skill sets to diversified firms will reinforce the effect of skills accumulated internally on workers' outside options. In our empirical work, we endeavor to separate the two mechanisms as much as possible, isolating the channel from organizational structure to worker skills.

A key feature of the model is that workers have bargaining power with the firm. This power arises endogenously because workers acquire costly (and therefore scarce) skills with a firm-specific component. A direct implication is that the bargaining power of high-skill workers exceeds that of low-skill workers, who do not have skills that are scarce in the labor market. Thus, the effect of increased outside options on relative worker wages will be most apparent among high skill workers.

Hypothesis 2. The relative wage advantage enjoyed by workers from diversified firms who move to "related" industries should be strongest for high-skill workers.

Prior finance literature on conglomerates emphasizes frictions in capital markets. If there are (also) frictions in labor markets, then diversified firms are better positioned to respond to changes in relative industry conditions by adjusting labor allocations. Diversified firms can shift labor internally to industries with good opportunities and away from declining industries. The ability to move labor more freely across segments offers diversified firms a valuable real option, and in turn can lead to more efficient hiring and firing decisions ex ante. For example, unlike focused firms, which may retain workers in bad times to avoid frictions in the external market if the industry is expected to turn around, diversified firms can move workers internally to better performing industries and, therefore, can adjust labor in a declining segment more aggressively.

Hypothesis 3. Diversified firms reallocate workers internally from declining to expanding industries and reallocation occurs at a higher rate than in the open market.

It follows from Hypothesis 1 that wages will be higher in diversified firms for a given level of productivity, since workers in diversified firms have higher outside options. However, diversified firms may also enjoy higher worker productivity due to more effective labor deployment (Hypotheses 3). Moreover, the broader skill sets of workers in diversified firms may themselves induce higher 
productivity by, e.g., spurring innovation in the production process.

Hypothesis 4a. Workers in diversified firms earn higher wages, controlling for standard observable characteristics.

Hypothesis $\mathbf{4 b}$. Labor productivity is higher in diversified firms than in focused firms operating in the same industries.

Our focus is on differences in the human capital stocks of diversified and focused firms. Thus, we generally compare wages of workers who have already invested in accumulating skills inside the firm instead of initial wage levels. Moreover, the internal labor markets in diversified firms may generate an insurance effect which cuts in the other direction; that is, workers may initially give up wages in return for the opportunity to remain inside the firm even if their own division fails. ${ }^{5}$ If so, then Hypothesis 4a is a possible, but not necessary implication (i.e., we only observe the net effect of diversification on wages in the data). Note that this insurance effect would be relatively more important among low-skill workers who do not have heightened outside options.

As a final step, we consider the relative stock prices of diversified and focused firms. A large finance literature establishes a "diversification discount": diversified firms trade at a discount relative to a portfolio of stand-alone firms operating in the same industries. Hypothesis $4 \mathrm{~b}$, in particular, suggests that diversified firms should generate higher cash flows than focused counterparts. However, the risk of those cash flows may be quite different from the risk of cash flows in focused firms. We argue that the bundles of skills workers develop in diversified firms are a form of organization capital. Since workers can transfer a fraction of that capital to a new firm, they must be paid wages in accordance with their outside options. Eisfeldt and Papanikolaou (forthcoming) argue that these outside options can have a systematic component if the productivity of organization capital in new firms is subject to a common technology shock. ${ }^{6}$ As a result, firms that invest

\footnotetext{
${ }^{5}$ Note, however, that the firm also recognizes its ability to reallocate workers internally and, as a result, does not need to retain as many workers in bad times to insure itself against future upturns in the industry. Thus, labor retention will be more sensitive to within-segment opportunities in diversified firms. So, this force could undercut the perceived insurance the worker receives from the firm.

${ }^{6}$ Atkeson and Kehoe (2005) and Lustig, Syverson and Van Niewerburgh (2011) also build models that include a common shock to the productivity of organization capital in new firms.
} 
more heavily in organization capital are more exposed to shocks that change the division of surplus between shareholders and workers, and their shareholders will demand a risk premium. Then, the cash flow-value relationship among focused firms does not provide an appropriate benchmark for valuing a segment of a diversified firm and we should see more of an apparent discount among diversified firms that operate in higher skill industries. ${ }^{7}$

Hypothesis 5. The "diversification discount" is strongest for diversified firms with a greater fraction of operations in high skill industries.

\section{Data}

We use worker-, firm-, and plant-level data from the U.S. Census Bureau to test our hypotheses. We identify individual plants and their ultimate owners (firm), geographic locations (state and county) and industries (4-digit SIC) using the Longitudinal Business Database (LBD). The LBD covers all non-farm establishments with paid employees in the U.S. since 1976. It also provides information on plant-level employment and payroll as well as information on plant birth or closure (if any).

We retrieve individual worker-level information - including wage, gender, and age - from the Longitudinal Employer Household Dynamics (LEHD) program. The LEHD data is constructed using administrative records collected from the state unemployment insurance (UI) system and the associated ES-202 program. It covers $96 \%$ of total wage and salary civilian jobs in the U.S. and is generally comparable from state to state. Wages reported to the state UI system include bonuses, stock options, profit distributions, the cash value of meals and lodging, tips and other gratuities in most of the states, and, in some states, employer contributions to certain deferred compensation plans such as $401(\mathrm{k})$ plans. $^{8}$ The data contain individual worker identifiers as well as firm and unit identifiers. Thus, we can track workers and their wages dynamically within and across firms.

\footnotetext{
${ }^{7}$ Note that it is unclear whether theories based on the inefficient internal allocation of capital can generate this prediciton, since physical capital is likely to be less important than human capital in such industries.

${ }^{8}$ See http://www.bls.gov/cew/cewfaq.htm for additional details.
} 
The Census Bureau currently provides access to employment records from 23 states through its Research Data Center (RDC). ${ }^{9}$ Missing data from uncovered states imposes some limitations on our analysis. First, we generally overstate unemployment rates in our sample: a worker may have a job in one quarter and not appear in the data the next due either to job loss or to migration to an uncovered state. Second, we cannot observe the entire labor force or all internal worker movement for firms which operate in both covered and uncovered states. Most of our analysis concerns changes in wages, rather than unemployment. As long as the factors affecting the decision of the state to opt into or out of the LEHD program are orthogonal to the determinants of (changes in) wages, our estimates should not suffer from selection bias. ${ }^{10}$ Moreover, the within-sample rate of migration to a new covered state - even following plant closure - is low (approximately $2 \%$ ). Thus, the potential impact of unobserved migration on our analysis is likely to be small.

We make several adjustments to the reported wages for our analysis. We use the quarterly consumer price index to compute real quarterly wages in beginning-of-1990 dollars. We also aggregate quarterly wages into annual real wages. Because of annual bonuses and other predictable seasonal variation, quarterly wages may not provide an accurate reflection of the worker's earnings and quarterly wage changes may not reflect real changes to the compensation contract. Thus, in any given quarter, we compute annual real wages for the preceding year as the mean real wage over the prior four quarters multiplied by four. We also require at least three consecutive quarters of wage data to include the quarter in the sample and use only interior quarters in the computation. The latter restriction is necessary since the first or last quarter's wage reflects payment for an unobserved fraction of the quarter. Finally, we exclude workers younger than 16 or who earn less than $\$ 10,000$ from our analysis. We identify the manager of the unit (firm) quarter-by-quarter as the worker with the highest wage in the unit (firm).

\footnotetext{
${ }^{9}$ All 50 states, the District of Columbia, Puerto Rico, and the U.S. Virgin Islands have been in the LEHD partnership since December, 2010. However, not every state partner has passed through the experimental production phase. As of March 2011, only 23 states had data available for reasearch purposes through the Census RDC.

${ }^{10}$ This is likely to be the case as often the constraint which prevents the Census from making data available to researchers is pre-existing state laws.
} 
Within the LEHD data, we can identify firms using tax reporting units: federal employer identification numbers (EINs), state employer identification numbers (SEINs), and state reporting "units" (SEINUNITs). State laws require firms to file quarterly reports which link individual workers to each of their SEINs. Thus, we can track worker movement across SEINs over time.

We use plant-level information from the LBD to identify multi-unit firms (i.e., firms operating multiple plants) and to measure firm-level diversification. We also use the LBD to identify plant closures. Since the LEHD data is available through the first quarter of 2004, we consider plant closures through 2001 so that we can track the outcomes of workers for (at least) 2 full years following a job change. We restrict the sample to plants with at least 50 employees to prevent our sample from being dominated by very small private ventures.

Because both Census data sources include firms' EINs, it is relatively straightforward to merge firm-level information from the LBD to the worker-level information in the LEHD data for singleunit firms. For multi-unit firms, however, it is not generally possible to assign individual workers uniquely to LBD plants since the LEHD data report tax units and the LBD reports physical business establishments. ${ }^{11}$ The internal bridge file at the Census, the LEHD Business Register Bridge (BRB), provides a link between the LEHD data and the LBD at various levels of aggregation. Its finest partition is at the EIN, state, county, and four-digit SIC code level. Thus, to achieve a match of workers (from the LEHD data) to a unique plant (from the LBD), we require that the LBD plant is unique within this partition.

To identify worker flows within and across firms, we use the firm identifiers provided in the LBD. Because workers in closing plants cannot remain in their original jobs, we can distinguish internal from external job changes by comparing the firm identifiers from the old and new jobs. ${ }^{12}$ If the firm identifier remains the same, then the worker changed jobs in the internal labor market.

When we turn to firm-level analysis in Sections III.D and IV.B, we use additional data from

\footnotetext{
${ }^{11}$ The relation between the numbers of plants and tax reporting units for a particular firm is unclear. In some cases, the number of plants exceeds the number of tax reporting units; however, in other cases, the opposite is true.

${ }^{12}$ More generally, changes in firm identifiers can be hard to interpret due to administrative changes in the way the firm reports its information and/or corporate restructuring.
} 
Compustat. We define industry $\mathrm{Q}$ as the median of the market value of assets scaled by the book value of assets within each 2 -digit SIC code. ${ }^{13}$ We also use Compustat segment data to compute the diversification discount for the subset of publicly traded firms. Following Lang and Stulz (1994), we measure the diversification discount among firms operating multiple business segments as the difference between the natural logarithms of the firm's imputed and actual market-to-book ratios. ${ }^{14}$ Imputed market-to-book for each segment of a diversified firm is the median marketto-book ratio among single-segment firms operating in the segment's 3-digit SIC code. Imputed market-to-book for the firm is the asset-weighted average of the imputed market-to-book ratios for each of the firm's segments. Finally, we use accounting data from Compustat to construct firmlevel controls (for the subsample of public firms). We measure ROA as EBITDA (oibdp) scaled by beginning-of-fiscal-year assets (at). Tangibility is property, plants, and equipment (ppent); cash stock is cash and short term investments (che); investment is capital expenditures (capx). Tangibility, cash stock, and investment are all scaled by beginning-of-fiscal-year assets. Book leverage is long term debt (dltt) plus debt in current liabilities (dlc) divided by the numerator plus common equity (ceq). Finally, we construct an indicator variable equal to one for firms that pay a positive cash dividend $(\mathrm{dv})$.

In Table I, we provide plant-level summary statistics of the data. In Panel A, we provide summary statistics for a random sample of plants from the LBD between 1993 and 2001. The average plant has 194 workers and a payroll of $\$ 6.83$ million. $58 \%$ of plants are part of multiunit firms and $42 \%$ are part of firms which operate in at least two distinct 2-digit SIC codes (diversified firms). In Panel B, we see that plants from multi-unit firms do not have significantly larger employment $($ mean $=202)$, but have larger payrolls (mean $=\$ 7.59$ million $) .55 \%$ of the plants come from the 23 states covered by the LEHD data.

\footnotetext{
${ }^{13}$ Market value of assets is the book value of assets (at) plus the difference between market and book equity. Market equity is the fiscal year closing stock price (prcc_f) times common shares outstanding (csho). Book equity is common equity (ceq) plus deferred taxes (txdb).

${ }^{14}$ Market value is measured as common shares outstanding (csho) times the fiscal year closing stock price (prcc_f) plus long term debt (dltt) plus debt in current liabilities (dlc) plus preferred stock (pstk). Book value is total assets (at).
} 
We also consider a sample of closing plants from the LBD over the same time period. Relative to the average plant, closing plants appear to be smaller (mean employment $=188$ ) and have smaller payrolls (mean $=\$ 5.3$ million). Only half come from multi-unit firms, but the fraction from diversified firms is similar to the overall sample (39\%). There are no obvious regional patterns in closure rates, but we observe a clear spike in closures in the recession year of 2001 .

Finally, we provide summary statistics for the subset of closing plants we can match to individual workers in the LEHD data. Relative to random closing plants, worker-matched plants are significantly less likely to be part of multi-unit firms (15\%). This difference occurs for two reasons. First, we only match plants which are unique within their firm, county, and 4-digit SIC and thus exclude cases in which multi-unit firms have more than one plant in this partition. Second, for consistency, we require the LEHD data to record the "death" of the reporting unit within 8 quarters of the reported closing in the LBD. The LEHD data will often include imputed records based on the last filing for quarters in which a firm fails to file its tax information, until it is clear that the plant has closed. Imputed records are more common among multi-unit firms since the firm can continue to operate despite closing one or more plants. Because our goal is to track workers displaced by closure, these records create serious attenuation biases for our analysis and must be dropped. Conditional on being part of a multi-unit firm, the fraction of plants that are part of a diversified firm is $69 \%$, which is similar to the overall LBD sample (71\%) and only slightly lower than the LBD closure sample (79\%). Matched sample plants are also smaller than the typical LBD (closing) plant, both among single- and multi-unit firms. ${ }^{15}$ In the full matched sample, mean employment is 134 and mean payroll is $\$ 2.33$ million. The matched sample also significantly undersamples the Northeast, most likely due to the exclusion of New York from the LEHD universe. Surprisingly, we do not observe a large spike in closures in 2001, as in the random LBD sample.

In Table II, we provide summary statistics at the worker level. In Panel A, we present statistics for a random sample of LEHD data worker-quarters. The average worker is 41 years old with 3.36

\footnotetext{
${ }^{15}$ This difference also arises due to our restriction to plants for which we observe closure in both the LEHD data and the LBD.
} 
years of tenure in the SEIN. Women make up $46 \%$ of the workforce. $10 \%$ of the workforce is Black, $4 \%$ Asian, 9\% Hispanic, and 5\% other non-white. The mean annual wage is $\$ 34,660$. Workers in multi-unit firms earn higher mean wages, particularly in diversified firms (mean single-unit = $\$ 30,613$; mean focused multi-unit $=\$ 33,527$; mean diversified $=\$ 37,121)$.

In Panel B, we provide summary statistics for the workers in the LBD - LEHD matched sample of closing plants. The mean worker is one year younger and women make up only $41 \%$ of the workforce. Most noticeably, mean wages are smaller $(\$ 29,933)$, likely reflecting the smaller plant size in the matched sample (Table I). The pattern in mean wages across firms with different organizational structures is also less pronounced in this sample. Because we can only identify individual workers in "isolated" plants, the multi-unit firms in our sample may be less diverse or complex than unmatched firms. If so, our results may understate the impact of such structures on the opportunity sets of workers and on-going investment in human capital.

\section{Diversification and Worker Mobility}

We use the worker-firm matched data described in Section II to test three hypotheses about worker mobility: (1) workers from diversified firms have greater mobility between the industries in which the firm operates, (2) this is particularly true among high skill workers and (3) diversified firms exploit this greater mobility by adjusting labor more aggressively in response to changing industry conditions. To measure mobility across industries, we use wage changes when workers change industries.

An immediate issue is the endogeneity of the job change decision. Worker allocation across jobs is the result of both a supply and demand decision. Firms can decide which workers they prefer to employ, but workers can also choose to accept a job offer, to remain in their current jobs, or to quit and search for new employment. This is particularly problematic when comparing workers who change industries to workers who remain in their original industries. Workers may be more likely to voluntarily accept jobs within their industries than in new industries. Wage changes in 
voluntary job changes are likely to be truncated below: workers will only change jobs if the new opportunity is more lucrative than their current job. However, wage changes for fired workers are likely to be truncated above. Then, we may observe relative wage losses among workers who change industries even if industry changes are not themselves costly.

We use plant closures as a way to disentangle supply- and demand-driven job changes. Workers displaced by plant closure cannot remain in their current jobs and the displacement is involuntary. Moreover, it is unlikely that displacement is related to skill or performance of individual workers. ${ }^{16}$ Thus, measured differences in the outcomes of workers across diversified and focused firms should reflect differences in the opportunities or skills of those workers rather than differences in the endogenous choice to switch jobs. Because workers have limited bargaining power when displaced, it is more likely that higher wages reflect higher outside options than the extraction of rents.

We compute the change in the annual real wage from two quarters prior to plant closure to the fourth quarter following plant closure. ${ }^{17}$ This computation implicitly restricts our sample to displaced workers who find a new job within the first three quarters following the closure. ${ }^{18}$ Though this restriction potentially biases downward our estimates of the wage impact of plant closure, our goal is not to measure the cost of displacement itself, but simply to use displacement as a common cause of job changes for all sample workers.

\section{III.A Hypothesis 1: "Related" Industry Changes}

We propose that diversified firms enjoy an advantage over focused firms in developing "generalist" workers whose skills have value across industries. To test this hypothesis, we compare the wage changes among displaced workers who move to a firm in a new industry in which their former firm

\footnotetext{
${ }^{16}$ This identifying assumption may fail for managers. Thus, we always include a control for managers in our regressions and confirm that our results are not driven by the very top of the wage distribution within the closing plant.

${ }^{17}$ We compute the annual real wage as defined in Section II. We winsorize the wage change at the $1 \%$ level to remove severe outliers.

${ }^{18} \mathrm{~A}$ worker re-employed in the fourth quarter following closure would not be included because we can compute the annual real wage starting only from the second quarter of employment. See Section II for details.
} 
also operates ("related industries") to the wage changes among displaced workers who move to a new industry in which their former firm does not operate ("unrelated industries"). If internal exposure to tasks across industries develops the skills of workers in diversified firms, those skills should translate more readily to the particular industries in which the diversified firm operates. Thus, we predict smaller wage losses among the set of workers who make such changes.

We restrict our sample to firms that only close a subset of their plants to ensure that all workers have the potential to find new jobs either inside or outside their original firms. In our regressions, we distinguish between workers who change jobs in internal and external labor markets. Wage changes when workers remain inside the firm may not reflect the workers' true outside options. Moreover, better workers may remain inside the firm following plant closure, making wage changes around internal and external moves difficult to compare. To minimize the impact of worker sorting on our estimates, we draw our main inferences by comparing only workers who make external job changes.

The sample consists of 42,354 workers across 697 firms. Within this subsample, $22 \%$ of the workers come from focused firms. Following closure, diversified firms are twice as likely to retain workers as focused firms (19.5\% versus 9.6\%). Of the workers retained by diversified firms, roughly one quarter change industries. Among workers who leave their firms, the probability of switching industries is similar between workers from diversified and focused firms (41\% versus 44\%). Given an external industry change, one third of the workers from diversified firms switch to industries in which their former firms operate. Though workers from diversified firms choose these "related" industries at higher rates, they account for less than $30 \%$ of all workers making the transition between any given industry pair. For completeness, we also test for differences in the length of unemployment spells for workers displaced from diversified and focused firms. Consistent with a worker-level advantage to diversification, we find that the unemployment spells of diversified workers are shorter on average, though the difference tends to be statistically insignificant.

We control for a number of demographic factors that might affect worker opportunities in our 
regressions. We include the natural logarithms of worker age and tenure, four separate race indicators (Black, Hispanic, Asian, and other minority), and indicator variables for managers and women. We also include the pre-job change wage level (in log form) to control for the unobserved component of ability that is uncorrelated with our demographic controls.

We also control for variation at the plant and firm level. We include measures of plant and firm size: the natural logarithms of employment in the worker's plant and firm. We also include the number of plants in the firm as a control for the availability of internal opportunities. And, we include an indicator variable for diversified firms (i.e., firms that operate in more than one 2-digit SIC code). All control variables are measured two quarters prior to plant closure. Finally, since firm size is an important determinant of wage levels (Oi and Idson (1999)), we control for the change in plant and firm size between the workers' old and new jobs. We include the differences in the natural logarithms of plant and firm employment and the difference in the number of plants between the old and new firms.

In Table III, we report estimates of the wage changes around displacement for our sample workers, distinguishing between workers who move to "related" and "unrelated" new industries. In Column 1, we include state, 2-digit industry, and year fixed effects in addition to the controls described above. We cluster standard errors by firm to correct for correlation in the residuals of workers displaced from the same firm. We find that when displaced workers move to a new firm, those who change industry perform worse than those who remain in the same industry, consistent with Neal (1995). The relative loss is roughly 14.4 percentage points and is significant at the $1 \%$ level. On the other hand, moving to an industry in which the original (diversified) firm operates (or, a "related" industry) erases the vast majority of the relative wage loss, confirming Hypothesis 1. We observe a significant 10.9 percentage point difference in the wage changes between the two groups.

We also address two additional endogeneity concerns. First, firms may close plants at different times and under different circumstances. For example, diversified firms may have a lower threshold 
for closing plants than focused firms since they can focus on their other remaining businesses. If so, workers moving to related industries may do better because they change jobs in better market conditions. The Column 1 specification includes year and industry effects, which should partially address this concern. In Column 2, we take an alternative approach, adding plant fixed effects and comparing only workers from the same closing plants. We find similar results.

A more serious concern is that the selection of industries inside a diversified firm is not random. Diversified firms may choose to operate in industries in which operations are more related. Then these synergies, rather than differences in worker skills, might explain the smaller relative wage losses among workers who move to a new industry in which their former employing firm operates. To address this concern, we add fixed effects for each pair of pre- and post-closure 2-digit SIC codes in the sample to the regression specification. Thus, we compare workers who switch to a new industry in which their former firm operates to workers who make the exact same industry change, but without potential exposure to the new industry within the initial employing firm. We report the results in Column 3. By including these fixed effects, we can no longer estimate the level effect of changing industries on wages. However, we observe similar patterns among the other variables of interest. We find a significantly positive effect of exposure to the new industry in the former employing firm, though we observe a decline in the magnitude of the estimate. Thus, our results cannot be explained solely by greater complementarity of the industries in which diversified firms operate than between the typical industry pair between which workers switch in the external market.

In addition to confirming Hypothesis 1, the regressions in Table III provide indirect evidence on the efficiency of wages within multi-unit firms. We see little evidence that displaced workers who remain inside their firm and industry outperform workers who leave their firm but remain in their original industry. This result suggests that wages inside such firms are not set inefficiently high; workers can attain similar wages in external markets. Similarly, workers who change industries inside the firm or move to a "related" industry outside the firm perform about the same as those 
who leave the firm but stay in their original industry. ${ }^{19}$ We also do not see an effect of diversification on wage changes independent from the effects of the types of job changes workers make. Thus, the results are consistent with compensation for workers' skills and outside opportunities (in specific industries) and do not suggest that diversified firms dissipate rents through excessive compensation or that workers from diversified firms are simply better on average than other workers.

We also perform several robustness checks on the evidence. We confirm that the wage advantage enjoyed by workers who move to industries in which their former firms operate does not dissipate over the two or three years after they reenter the job market. We find no additional gains or losses in relative wages, but stable differences of the same magnitude as the estimates in Table III among workers who make no additional job changes. We also find that our results are particularly strong among workers with longer tenure inside their original firms, consistent with the accumulation of general skills over time in diversified firms.

Overall, our analysis demonstrates distinct differences between labor in diversified and focused multi-unit firms. Diversified firms have richer internal labor markets than focused firms which allow workers to develop general skills with application across a wider range of industries. As a result, these workers can change industries without experiencing the costs typical of such changes in external markets. Though our key tests emphasize external moves to isolate a credible measure of outside options, we will return to the functioning of internal labor markets and the benefits to the firm in Section III.D.

\section{III.B Alternative Explanations}

Before testing Hypothesis 2, we briefly consider several alternative explanations for the labor market advantage enjoyed by workers from diversified firms.

Worker Sorting. We argue that workers from diversified firms develop general skills which apply

\footnotetext{
${ }^{19}$ The former effect is statistically insignificant in two of three specifications. Moreover, the difference in wage changes for workers who change industries inside the firm and workers who change industries outside the firm, but within the set of industries in which the firm operates is not statistically significant.
} 
across the set of industries in which the firm operates. Thus, they make easier transitions within that particular set of industries. However, among the set of workers displaced from diversified firms who change industries, it is possible that the higher ability workers move to "related" industries while the lower ability workers move to "unrelated" industries and it is those differences in ability that explain the wage differences in Table III. First, it is not obvious why we would expect this type of sorting if there is not a better worker-firm match in "related" industries, as we propose. Moreover, we control in our regressions for the pre-closure wage, which should capture differences in ability across workers. Nevertheless, we take several additional steps to address this possibility. First, we compare the observable characteristics of workers in the two groups (Table IV). We do not see significant differences in the worker-level characteristics of workers from diversified firms who move to "related" industries and workers from diversified firms who move between the same industries, but for whom the new industry is "unrelated." The sole exception is the percentage of Hispanic workers, which is significant at the $10 \%$ level. At the firm level, we do see, not surprisingly, that workers in the former set come from larger firms (which have larger sets of "related" industries), but not from larger plants. Given the similarity of observables, it is unclear why there would be unobservable differences in ability across groups, particularly since pre-closure wages (which are not significantly different) should proxy for such differences. We also run two additional regression tests to further address the sorting hypothesis. First, we ask whether our results rely on comparisons of workers who are far apart in the pre-closure wage distribution. If so, then our estimates might be sensitive to the specification of the wage control. To test this hypothesis, we re-estimate the regression specification from Column 3 of Table III, but interacting the SIC pair fixed effects with fixed effects for categories of pre-closure wages. Thus, only workers who are sufficiently close in the wage distribution contribute to the estimates. We find that this approach strengthens our results; for example, using four wage groupings $(\leq \$ 25 \mathrm{~K}, \$ 25 \mathrm{~K}-\$ 50 \mathrm{~K}$, $\$ 50 \mathrm{~K}-\$ 100 \mathrm{~K},>\$ 100 \mathrm{~K})$ the estimated benefit of moving to a "related" industry is $4.4 \%$, significant at the $1 \%$ level. The results are even stronger using finer partitions. We take a similar approach 
to ensure that the differences in firm size do not somehow interact with the effects of interest. We find that comparing workers from firms that are close together in the size distribution only strengthens our results.

Location Effects. Diversified firms may operate plants in systematically different geographic locations from focused firms. Suppose, for example, that diversified firms are more likely to operate in urban centers or in areas with more active local markets (at a finer level than the state, for which we have already controlled). Then, the better outcomes among workers who are displaced from diversified firms might reflect these better local opportunities and not broader skill sets obtained through work experience in the diversified firms. We test this hypothesis in two ways. First, we measure the distance between each displaced worker's old and new jobs. Since we know the county in which each job is located, we compute distance as the number of miles between the center of the two counties. In Column 1 of Table V, we report the results of re-estimating the regression specification from Column 3 of Table III, including the natural logarithm of the distance between the old and new jobs and its interactions with the indicators for internal job changes and industry changes as additional controls. ${ }^{20}$ We find some evidence that workers who move greater distances to their new jobs experience relative wage losses, though the significance of the estimate is weak. However, controlling for distance has no impact on our effect of interest: workers who leave their firm, but move to "related" industries experience smaller wage losses than other workers who move between the same industries.

Second, we control for the availability of jobs in the county in which the worker's closing plant operates. In Column 2 of Table $\mathrm{V}$, we report the results of re-estimating the regression from Column 1, but including instead the natural logarithms of the total number of plants operating in the county, the number of plants in the worker's original SIC operating in the county, and the number of plants in the worker's SIC after displacement operating in the county. All three variables are measured in the year prior to the plant closure. We also interact all three measures

\footnotetext{
${ }^{20}$ For brevity, we do not report the estimates of the demographic and firm controls; however, the estimates are not materially different from those reported in Column 3 of Table III.
} 
of local opportunities with the indicators for internal job changes and industry changes. We again find little impact on the effect of interest. As a final robustness check, we re-estimate the regression controlling for total employment, rather than the number of plants, in the county and old and new SICs (and interactions with the indicators for internal and industry changes). The results are qualitatively unchanged.

Information Effects. A third alternative is that workers in diversified firms have better information about available opportunities in the industries in which their diversified firms operate. However, they do not have skills that are better suited for those industries than the typical worker who makes the same industry switch in the external market. In this case, workers in diversified firms should time their industry changes better than other workers. That is, the wage advantage relative to other workers who make the exact same industry change comes from making the change when opportunities in the new industry are better (or, equivalently, opportunities in the old industry are worse). To test this hypothesis, we re-estimate the regression specification from Column 3 of Table III, but interacting the industry pair fixed effects with the year fixed effects. Thus, we compare only the changes in wages for displaced workers who switch between the same two industries at the same time. Though our estimates are less powerful, the coefficient of interest is similar in magnitude $(0.033, p$-value $=0.109)$. Thus, better timing of the job change does not appear to explain our results. We also estimate an alternative specification of the regression from Column 3 of Table III in which we estimate separate effects for workers who move to a "related" industry depending on whether their former firm operates in the same county as the new firm. If the advantage is due to information, then our results should be stronger for workers who move to a county in which the old firm also operates. In this case, it is more likely that workers from the two firms would interact and that workers who make "related" industry changes might do so through referrals made by their co-workers in those industries. However, we find similar effects regardless of the location of the new firm.

Prior Experience and Worker-Firm Matching. An important alternative to the hypothesis that 
workers develop general skills and industry mobility within diversified firms is the possibility that workers already possess those traits before they are hired (though, in either case, our results identify important differences in the workforces of focused and diversified firms). To test this hypothesis, we consider the work histories of our sample of displaced workers prior to their employment in the closing plants. We define an indicator variable which takes the value one if the worker ever worked in her new post-closure SIC prior to working in the closing plant. We then re-estimate the regression from Column 3 of Table III including the indicator and its interactions with the indicators for internal job changes and SIC changes as additional controls. We also allow for different effects of moving to a new industry in which the worker's former firm operates depending on whether or not the worker has experience in the new SIC before joining the diversified firm. We report the results in Column 3 of Table V. We find that prior experience in the new $\mathrm{SIC}$ is not responsible for our results. We do not see significant differences between the wage changes of workers who make a switch to an industry in which their former firm operates and who have or do not have prior experience in the SIC outside the diversified firm. We also do several robustness checks on this evidence. We allow for different effects depending on the amount of time the worker spent in the new SIC, with little impact on the results. We also consider the impact of data censoring on our conclusions. Because our worker data begins in 1991, we do not observe full worker histories for all workers in the sample. When we consider only the subsample of workers who were 18 or younger in 1991, we find that the frequency of prior experience in the post-closure SIC is roughly the same as in the overall sample (and, in fact, slightly larger). Thus, censoring does not seem to create an undersampling problem. Moreover, we continue to find that prior experience cannot explain the ease with which workers from diversified firms change industries on this reduced sample.

Classification of Industries. Another possibility is that the meaning of particular industry classifications differs across focused and diversified firms. For example, consider a diversified firm that operates in SIC codes 24 (lumber and wood products) and 25 (furniture and fixtures). The 
firm's operations in SIC 24 may be more similar to the typical firm operating in SIC 25 than in 24 if there is an input-output relation between the two units. In this case, the workers classified in SIC 24 might be classified in SIC 25 were they not in the diversified firm, explaining their relative mobility to SIC code 25. Note, however, that this story also implies that intra-industry changes for workers from diversified firms are measured with error. In particular, we should see not only that workers from diversified firms perform better when they switch to industries in which the diversified firms operate, but also that they do worse when they move to a new firm operating in the same industry. We see no evidence of the latter effect in our data (note again the insignificant coefficient estimate on the diversification indicator in Table III). The mis-classification story also is most plausible for closely related industries. As another way to test the hypothesis, we reestimate the regressions from Table III, but considering only changes between 1-digit SIC codes. If anything, we find that our results are stronger using this more restrictive definition of industry changes. We continue to find a relative wage advantage among workers who move to a new firm in a different industry, but in which their old firm also operates.

Overall, the evidence supports the hypothesis that diversified firms cultivate generalist workers. The "boundaryless" model of a conglomerate appears to pay dividends in terms of developing worker skills that are in high demand in the labor market. In Section IV, we address more directly the value of such skills to the firm.

\section{III.C Hypothesis 2: Wage Changes by Worker Skill Levels}

Having explored competing explanations of our key findings, we next turn to our second hypothesis: the relative wage advantage enjoyed by workers from diversified firms who move to "related" industries should be strongest for high-skill workers, whose skills are scarce in the marketplace and for whom high human capital is the main driver of productivity.

We test this prediction in two ways. First, we partition the sample using workers' pre-closure wages. We consider four groupings: workers who earn less than $\$ 25,000$ in real annual wages, 
workers who earn $\$ 25,000$ to $\$ 50,000$, workers who earn $\$ 50,000$ to $\$ 100,000$, and workers whose wages exceed $\$ 100,000$. Workers in the lowest wage group are likely to hold low-skill positions; workers earning in excess of $\$ 100,000$ are likely to be high ability, white collar workers. We reestimate the regressions from Table III, including indicators for each wage group in lieu of the natural logarithm of the pre-closure wage. We also allow for a different impact of industry changes in each group. And, we estimate the impact of moving to a new industry in which the worker's former firm also operates separately in each wage group. We present the results in Panel A of Table VI. ${ }^{21}$ Across all three specifications, we find that high-wage workers benefit the most when they move to a new industry in which their old firms operate. Interestingly, among low wage workers the effect appears to be driven by differences in the pairs of industries between which workers switch. When we include fixed effects for pre- and post-closure 2-digit SIC pairs, the effect vanishes in this wage grouping. As we move to higher wage groupings, however, we see a monotonic increase in the benefit achieved by workers who move to a new industry in which their old firms operate, even relative only to workers who make a switch between the same industry pairs.

As a second test of our prediction, we construct a more direct measure of high- and lowskill vocations. We collect information from the Bureau of Labor Statistics on the frequencies of workers across Standard Occupational Classification (SOC) codes for each 2-digit SIC in our sample. We classify 2-digit SOC codes less than 29 as high-skill vocations. These groupings include, for example, management occupations, business and financial occupations, computer and mathematical science occupations, and architecture and engineering occupations. We group jobs with SOC codes higher than 29 as low-skill positions. ${ }^{22}$ Examples in this category include food preparation and serving, office and administrative support, and construction positions. We then

\footnotetext{
${ }^{21}$ We again omit coefficient estimates for the demographic and firm controls for brevity, but they are similar to those reported in Table III.

${ }^{22}$ As a robustness check, we classify SOC codes in which the median worker salary is above the overall median wage as high skill industries. The only meaningful change is that sales positions move from the low to high skill grouping. All of our results are qualitatively unchanged using this alternative definition of high skill vocations.
} 
compute the percentages of workers in each 2-digit industry who work in high and low skill positions. ${ }^{23}$ We classify industries in which the fraction of high-skill jobs is above the median as "high skill" industries. These industries employ $64 \%$ of our sample workers. Strongly represented in this grouping are services industries: among the top 10 industries by percentages of skilled jobs are engineering, accounting, research, management, and related services (SIC 87); legal services (SIC 81); and health services (SIC 80). Also represented in the top 10 are finance industries (insurance carriers (SIC 63) and holding and other investment offices (SIC 67)). At the opposite end of the spectrum, we find among the bottom 10 low skill industries food stores (SIC 54), automotive dealers and gasoline service stations (SIC 55), eating and drinking places (SIC 58), textile mill products (SIC 22), and apparel and other finished products made from fabrics and similar materials (SIC 23). While service industries tend to fall in the high skill grouping and retail trade industries in the low skill grouping, manufacturing industries are fairly split between the two categories. High skill manufacturing industries appear to be groupings with high proportions of engineering or natural science jobs; for example, electronic and other electrical equipment (SIC 36), industrial and commercial machinery and computer equipment (SIC 35), chemicals and allied products (SIC 28), and petroleum refining and related industries (SIC 29). Notably, our skill categories - and particularly the high skill group - appear to be absorbing states: only $26 \%$ of workers move from a high skill to a low skill position and $44 \%$ from low to high.

We re-estimate our three regression specifications including an indicator for high skill industries interacted with the indicator for industry changes. As with the wage groupings above, we estimate separate effects of moving to a new industry in which the worker's former firm operates for high skill and low skill industries. We report the estimates in Panel B. We find that workers benefit most from exposure to other industries in their diversified firms when they work in high skill industries. We also see a similar pattern to the one uncovered by the wage partition: the effect for workers in

\footnotetext{
${ }^{23}$ Ideally, we would classify individual workers based on the SOC codes of their positions; however, worker-level SOC codes are not available in any Census data available for research purposes. We only observe the fraction of workers with each SOC code at the 2-digit SIC level.
} 
low skill industries disappears when we compare them only to other workers who switch between the same two industries. Thus, for low skill vocations, the benefit of diversification may derive more from synergies in production processes - leading to non-random selection of which SIC codes are grouped together - than from human capital gains. On the other hand, the effect remains strong and significant for workers in high skill industries. ${ }^{24}$ We also estimate a specification in which we subdivide the outcomes for workers who originate in high and low skill jobs depending on whether their new position belongs to a high or low skill group. Focusing on the specification with SIC pair fixed effects, we do not see an impact of moving to an industry in which the worker's former firm operates for either type of transition by a worker who originates in a low skill job. On the other hand, workers who originate in high skill jobs benefit whether they move to another high skill or to a low skill position.

Overall, the evidence confirms a key prediction of our hypothesis: the impact of diversification on worker skills is most keenly felt among workers of high ability and in industries in which human capital is a key driver of productivity.

\section{III.D Hypothesis 3: Diversification and the Redeployment Option}

Our evidence suggests that the opportunities and incentives to acquire general skills inside diversified firms provide benefits to the firms' workers. Next, we ask whether they also benefit the firm. To begin, we test Hypothesis 3. Our setting is analogous to studies that ask how diversified firms allocate scarce investment resources across divisions with differing opportunities, but focuses instead on labor allocation. If there are constraints on the ability to hire workers with appropriate skills in the external market, do diversified firms re-allocate workers internally to the industries with the greatest opportunities in response to shocks? ${ }^{25}$ And, does this reallocation exceed the reallocation of human capital across industries in the external market?

\footnotetext{
${ }^{24}$ The between-group difference is marginally insignificant ( $p$-value $\left.=0.1093\right)$.

${ }^{25}$ It is important to note that this is only one mechanism through which the firm may benefit from cultivating generalist workers. For example, we do not measure directly the potential for improved innovation (e.g., by creating more interdisciplinary product improvements).
} 
To test our hypothesis, it is important to isolate internal industry changes that are initiated by the firm and not the worker. Thus, we continue to focus on the sample of workers displaced by plant closure. Though this restriction removes worker-initiated moves, workers still have the choice to leave the firm. So, our estimates provide a lower bound on the amount of reallocation desired by the firm. We test the first part of our hypothesis in two steps within a Heckman selection model. We consider the set of diversified firms. In a first stage probit regression, we estimate the probability a displaced worker is retained inside the firm as a function of worker and firm characteristics. We include our usual indicators for race, gender, and managers together with continuous controls for worker age, tenure and pre-closure wage. We also include our usual set of firm size controls: the number of plants and the natural logarithms of plant and firm employment. Finally, we include four additional controls to capture differences across workers in the costs of moving or switching industries: the natural logarithms of the number of plants in the same county and 2-digit SIC code as the worker's closing plant, the total number of plants in the county, and the number of plants in the county in the worker's quarter $t+4 \mathrm{SIC}$ code as well as an indicator for whether the worker was born in the state in which the closing plant is located. We construct a measure of the future opportunities within the firm by considering the firm's industry portfolio. We compute an employee-weighted average of industry Q across the industries in which the firm still operates in the year following the plant closure and include it as an independent variable. ${ }^{26}$ To proxy for expected growth in the worker's current industry, we also include the realized difference in the natural logarithm of industry $\mathrm{Q}$ from year $t+1$ to year $t+3$. Though we use future values as an independent variable, reverse causality is not a major concern since the unit of observation is an individual worker and we measure future performance at the industry level. In Column 1 of Table VII, we report the results. We find that firms are significantly more likely to retain workers

\footnotetext{
${ }^{26}$ We restrict our attention to the firm's top five industries by employment. These five industries contain more than $99.6 \%$ of the total firm payroll. For the subset of firms with more than 20 SIC codes, the percentage is roughly $84 \%$. We use the median value of $\mathrm{Q}$ in the 2-digit SIC code among publicly traded firms in the Compustat universe. Thus, we implicitly assume that industry $\mathrm{Q}$ as measured in public firms is an appropriate proxy for industry opportunities in both the public and private firms contained in our sample.
} 
inside the firm when their future opportunities are strong. The marginal effect of firm $\mathrm{Q}$ on the probability of staying in the firm (at the mean of independent variables) is $10 \%$, compared to a baseline probability of $19.5 \%$.

Before turning to the second stage, we ask whether the probability of retention is affected by worker skill. To provide worker-level variation, we use pre-closure wages as our measure of skill. ${ }^{27}$ In Column 2, we report the results of re-estimating the specification from Column 1 on the subsample of workers with pre-closure wages above the plant median ("high-skill workers"). In Column 3, we report results on the complementary sample of relatively low skill workers. We find that the sensitivity of the choice to retain workers in the diversified firm to internal opportunities is stronger for high-ability workers. Thus, diversified firms take advantage of their internal supplies of skilled workers at times when their marginal productivity is likely to be high and when they are particularly likely to be scarce in the external market.

Next, we turn to the second stage of our Heckman model, estimating the likelihood the firm reallocates workers they choose to retain inside the firm to a different 2-digit industry. We include the same set of controls as in the first stage with the exception of the weighted average of industry Q. Thus, our identifying assumption is that the firm's overall prospects determine its decision to retain a worker inside the firm, but do not determine to which particular industry the firm allocates the worker. The variable of interest in the second stage, instead, is expected growth in the worker's pre-closure industry, measured by the realized difference in the natural logarithm of industry $\mathrm{Q}$ from year $t+1$ to year $t+3$. We estimate the second stage as a linear probability model; thus, we can interpret the coefficient estimate on the change in industry $\mathrm{Q}$ as a marginal effect: the increase in the probability the firm reallocates a worker to a new industry as expected growth in the current industry declines is roughly 0.23 at the mean of the independent variables. Thus, our results confirm the first part of Hypothesis 3: the decisions of diversified firms to retain workers and to reallocate them within the firm depend positively on the firm's future prospects

\footnotetext{
${ }^{27}$ The results are qualitatively similar using industry-level variation in SOC codes to measure skill, as in Section III.C.
} 
and on the relative opportunities of the firm's segments.

We also ask whether the reallocation of workers out of a declining industry happens at a faster rate in diversified firms than in the external market. For this test, we consider the entire sample of displaced workers who found jobs by quarter $t+3$, including workers from both single- and multiunit firms. We estimate a logit regression with a dependent variable indicating that the worker moved to a job in a new 2-digit SIC code in the year following job loss. We include indicator variables for multi-unit and diversified firms. The variable of interest, then, is the interaction of the indicator for diversification with our measure of expected growth in the worker's current industry. Otherwise, we replicate the specification from Column $4 .^{28}$ We report the results in Column 5. We do not observe a significant relation between the expected trend in industry value and the likelihood that the worker switches industries in general. However, we see that workers in diversified firms are significantly more likely to switch industries when the expected growth rate of their current industry is low. The coefficient estimate on our main variable of interest ( $C h g_{-} Q$ * Diversified) has a negative sign and is significant at the $5 \%$ level. Because the logit regression is nonlinear, the coefficient estimate on $\mathrm{Chg}_{-} Q{ }^{*}$ Diversified is not equal to the interaction effect. We compute the marginal effect of the interaction on the probability of switching industries at the mean of the independent variables to be a significant 0.19 . Thus, we also confirm the second part of Hypothesis 3: diversified firms reallocate workers to industries with better opportunities at a higher rate than the external market. This ability to adapt more easily to changing market conditions - as a result of the increased mobility of labor - is likely to generate significant value for the firm.

\footnotetext{
${ }^{28}$ The choice to estimate a logit regression rather than a linear probability or probit model does not impact our results.
} 


\section{Worker Mobility and Firm Value}

\section{IV.A Hypothesis 4: Diversification, Wage Levels and Productivity}

Our results thus far suggest that diversified firms benefit from richer internal labor markets: they enjoy a greater ability to adjust labor in response to changing industry opportunities. Next, we provide evidence of the direct impact of diversification on cash flows. In particular, we examine the two mechanisms in Hypothesis 4: (1) worker wages in diversified firms should be higher even controlling for worker characteristics - because workers have higher outside options and (2) productivity of labor in diversified firms should be higher. As long as there is no other diversified firm with the same skill-weights in its production function, both the firm and the worker will receive rents from diversification.

When we consider wage levels (rather than job changes), focusing on workers in closing plants no longer provides an identification advantage. Thus, we test our hypothesis on the random sample of 251,440 worker-quarters described in Section II. ${ }^{29}$ We estimate a standard wage regression. The dependent variable is the natural logarithm of the real annual wage. As independent variables, we include the natural logarithms of worker age and tenure, four separate race indicators (Black, Hispanic, Asian, and other minority), and indicator variables for managers and women. We also include the number of plants in the firm, an indicator for multi-unit firms, ${ }^{30}$ and the natural logarithms of employment in the worker's SEIN (or, firm-unit) and employment in the firm. Our variable of interest is an indicator for firm diversification (or, operation in multiple 2-digit SIC codes). We include state, year, and 2-digit SIC code fixed effects and continue to cluster standard errors at the firm-level.

We report the results in Column 1 of Table VIII. The estimates of the controls conform to the usual patterns in the literature. More experienced workers earn higher wages (age, tenure).

\footnotetext{
${ }^{29}$ As an additional robustness check, we also use this random sample to replicate our key regressions from Table III. We find qualitatively similar patterns, confirming the external validity of our estimates on the closure subsample.

${ }^{30}$ Both the multi-unit indicator and the number of plants are computed using information from the LBD. Plants are LBDNUM under the firm's LBD firmid. Multi-unit firms have more than one plant.
} 
Workers in larger units and in firms with multiple plants also earn higher wages (Oi and Idson (1999)). We also estimate a significant gender wage gap of $28 \%$. This estimate is in line with Altonji and Blank (1999) who report a 22\% gap using data from the March 1996 Current Population Survey (which falls within our sample period). Turning to the effect of interest, we find that workers in diversified firms earn a $2.1 \%$ premium over workers in other firms.

Given the correlation of diversification and firm size - most notably that all of the largest firms are diversified - we take additional steps to separate the effects to the greatest degree possible. The reported estimate appears to be a lower bound of the effect of diversification: We find no additional loss of explanatory power if we include the square of firm size (as the sole additional control or in addition to the squares of the number of plants and plant size) or if we control for size less parametrically by including, for example, dummies for each decile of the size distribution. Thus, we conclude that workers in diversified firms indeed enjoy a wage premium relative to peers in focused firms.

We also test whether the higher wage bills in diversified firms are correlated with the fraction of workers in high-skill industries, for whom we estimate higher outside options in Section III.C. We again use industry-level variation in SOC codes to define "high-" and "low-" skill industries. ${ }^{31}$ We find higher wages among diversified firms operating more intensively in high-skill industries (Column 2). Moreover, the effect of diversification turns negative once we include the interaction of the diversification indicator with the fraction of workers in high-skill industries. Thus, a diversified firm with only low-skill workers can pay lower wages than a focused firm. In this case, workers cannot command a wage premium (since they do not have scarce skills) and may accept a discount due to an "insurance effect" provided by the internal labor market of the diversified firm.

Schoar (2002) proposes rent dissipation through higher wage payments to workers as a valuedestroying consequence of corporate diversification. She provides evidence of larger aggregate wage bills in diversified firms and, in particular, higher "supplementary labor costs." However, she does

\footnotetext{
${ }^{31}$ Given that wages are the dependent variable, we cannot use wages as a proxy for skill in this context.
} 
not have worker-level data, making it difficult to control for worker heterogeneity across firms. Moreover, it is unclear to what degree the estimates of supplementary labor costs, like fringe benefits, can be attributed to rank-and-file workers. Our analysis demonstrates that (skilled) workers in diversified firms indeed receive a wage premium over workers in focused firms, even after including detailed controls for workforce composition (experience, race, gender, etc.). However, our results also suggest that diversification facilitates improvements in worker skills and opportunities. Thus, higher wage payments do not necessarily indicate rent dissipation, since workers in diversified firms can also obtain higher wages outside their firms.

Next, we test whether diversified firms indeed receive higher labor productivity in return for their heightened investments in human capital. We consider two measures of labor productivity: the ratio of firm sales to employment and the ratio of firm sales to payroll. Our measures are similar to the measures in Haltiwanger, Lane and Spletzer (1999). Foster, Haltiwanger and Krizan (1998) show that the sales to employment ratio is highly correlated with multifactor productivity in U.S. manufacturing firms. ${ }^{32}$ We match each segment of a diversified firm to focused firms in the same 2-digit industry in the same year and from the same size and age groupings. We define six size groups as follows: employment $\leq 20,20-50,50-100,100-250,250-500$, or $>500$. We define the following five age groups: years of operation $\leq 5,5-10,10-15,15-20$, or $>20$. Thus, within each industry and year, segments are assigned to one of thirty unique groups based on their size and age. We use the median sales to employment (payroll) ratio of the matched group of focused firms multiplied by the actual employment (payroll) of the segment to compute the predicted sales of the segment. The total predicted sales of a diversified firm is the sum of the predicted sales of all of its segments. We then compute the difference between the actual sales and predicted sales, in natural logarithms. We exclude diversified firms if they operate a segment that cannot be matched to a set of focused firms or if they operate a segment with a one-digit SIC of 0 (agriculture), 4

\footnotetext{
${ }^{32}$ We cannot estimate total factor productivity since we do not restrict our sample to manufacturing firms (for which data on capital stocks is available). The tradeoff is that our sample is far more representative of the U.S. economy.
} 
(utilities), 6 (financials) or 9 (public sector).

In Table IX, we report the mean difference between predicted and actual sales. We cluster standard errors by year to correct for macroeconomic correlation in productivity across firms. In Column 1, we use the ratio of sales to employment as our measure of labor productivity in performing the computation. We find a significant and positive effect: sales in diversified firms are roughly $9 \%$ higher than we would expect given the contemporaneous productivity of similar-sized focused firms in the industry that are at the same point in their life cycle. In Column 2, we add controls for firm age and size, despite the matching criteria described above. We also add a measure of worker skill inside the firm: the percentage of workers in "high-skill industries," again defined as in Section III.C. We find that the difference between predicted and actual sales increases as the percentage of high skill workers - for whom productivity is most likely to be enhanced by the cross-industry opportunities in diversified firms - increases. In Columns 3 and 4, we repeat the exercise, but using the ratio of sales to payroll as our measure of labor productivity. We find again that diversified firms outperform their focused matches. Here, we see that diversified firms enjoy an advantage even in low-skill industries. A possible explanation is the "insurance effect" in wages (see Table VIII). Low-skill workers do not have elevated outside options, but enjoy the enhanced internal opportunities in diversified firms. Thus, payrolls for diversified firms in low-skill industries are lower. ${ }^{33}$ The difference in sales between diversified firms and their matches is even higher for firms operating in high-skill industries. Though the magnitude is smaller than the predicted sales difference in Panel A, this result is expected since high skill workers in diversified firms extract some of the surplus from their higher productivity by demanding higher wages.

We also perform an additional robustness check to ensure that there is sufficient overlap between our treated and control samples. Since segments of diversified firms make up the bulk of the upper tails of the size and age distributions, we confirm that our results hold if we eliminate both tails

\footnotetext{
${ }^{33}$ Another potential mechanism generating a difference between the predicted sales using employment or payroll is a higher fraction of part-time workers in diversified firms. These workers are included in LBD aggregate employment, but our filters will drop them from our LEHD sample in most cases.
} 
from the sample. Overall, our results confirm Hypothesis 4: diversified firms pay higher wages, but receive more "bang for their buck." Labor provides a larger increment to cash flows than it does in similar focused firms.

\section{IV.B Hypothesis 5: The Diversification Discount}

Our analysis demonstrates that the labor stocks of diversified firms are significantly different from those of focused firms operating in the same industries. Workers from diversified firms have heightened mobility across the set of industries in which their diversified firms operate and, therefore, command extra compensation. The skills and expertise that underlie this mobility are a form of organization capital for the diversified firm. As such, it can carry a risk premium in financial markets and can generate a cross-sectional discount in the prices of publicly traded diversified firms relative to the median focused firms in their industries. Moreover, the discount should be highest for diversified firms with the largest stocks of organization capital (Hypothesis 5). Thus, the labor differences we identify are consistent with both higher productivity (or cash flows) among diversified firms and with a discount in equity markets.

As a final step, we test for a link between the diversification discount and worker mobility. To conduct this test, it is necessary to restrict our sample to publicly traded firms, for which we observe equity prices. We also require a measure that captures differences in the external mobility of workers across diversified firms. Because we only observe workers in the LEHD data for 23 U.S. states, we do not observe the full workforces among large diversified firms. Though this is not an impediment for our worker-level analyses, it could introduce serious biases in aggregating the individual worker-level data to create such a firm-level measure. As an alternative, we use our proxies for high- and low-skill industries from Section III.C to capture differences across firms in worker mobility. In particular, we ask whether diversified firms that hold a higher proportion of their assets in business segments operating in high-skill industries have higher discounts than firms that operate more intensively in low-skill industries. 
In Column 1 of Table X, we report the average diversification discount among publicly-traded multi-segment firms during our sample period of 1992 to 2004 . We find that such firms receive a discount of roughly 10\%, significant at the $1 \%$ level. In Column 2, we add a continuous measure for the percentage of firm assets in high-skill industries. We find a coefficient estimate that is positive and significant at the 1\% level. Economically, a firm operating 100\% in high-skill industries would have a discount roughly twice as large as a firm operating 100\% in low-skill industries. In Column 3, we add several firm-level controls to the regression. To control for differences in the discount driven by differences in profitability we include firm ROA. We also include firm size, asset tangibility, investment, cash holdings, book leverage, and an indicator for dividend payers to capture differences in opportunities and the ability to access capital markets. Finally, we include year effects to capture macroeconomic patterns in firm composition and stock prices. We find little impact on the magnitude of our estimate of the effect of worker-skill on the discount. Finally, in Column 4, we eliminate all firms which operate a business segment in the financial industry (1-digit segment $\mathrm{SIC}=6$ ). Again, our results are virtually unchanged.

We perform a number of additional robustness checks on the evidence. We experiment with the definition of unrelated segments (i.e., total number of business segments vs. segments in different 3-digit SIC codes vs. segments in different 2-digit SIC codes) with little qualitative impact on the results. We also use sales based multiples rather than asset based multiples to measure the discount (following Berger and Ofek (1995)) and compute the percentage of sales from high-skill versus low-skill industries, again with little impact on the results.

Overall, we find that diversified firms that operate in industries that employ more high-skilled, highly mobile workers receive a larger discount in the cross-section (relative to the median standalone firm operating in their industries). Taken together, our results suggest that a diversification discount need not reflect inefficient operation of the diversified firm. To the contrary, diversified firms can generate higher cash flows, yet carry a risk premium due to larger stocks of organization capital. Thus, it does not follow that conglomerate firms would be worth more separated into 
their constituent parts than as a whole: the resulting firms would generate smaller cash flows by giving up the benefits of "boundaryless" operations, but would retain more mobile workers than the median firms in their industries (at least for as long as they retained their current workforces). In this case, they would continue to carry a risk premium. An interesting question, but beyond the scope of our cross-sectional analysis, is to consider the importance of these factors in the original decision to diversify.

\section{Conclusion}

We use a unique approach which combines worker-firm matched data from the U.S. Census Bureau's LEHD program with plant- and firm-level data from the LBD and valuation data from Compustat to look inside the black box of internal labor markets. We find significant differences between the workforces of diversified and focused firms. In particular, diversified firms cultivate general worker skills that increase worker mobility across industries. Diversified firms benefit from the resulting real option to redeploy labor to sectors with greater marginal returns in response to economic shocks and experience greater labor productivity.

We use plant closures as a way to separate voluntary from involuntary job changes and to compare credibly the outcomes of workers who make job changes. We find that workers who leave a diversified firm, but move to a new industry in which their former firm operates experience only a modest wage loss, significantly less than workers who move to an entirely new industry. The result is consistent with the hypothesis that diversified firms foster and benefit from the skills workers develop by working synergistically across the firms' lines of business.

We address several competing explanations of our evidence: differences in the local markets in which diversified and focused firm operate, differences in the information available to workers in diversified firms about cross-industry opportunities, differences in industry classifications across diversified and focused firms, and differences in the work histories of workers prior to joining diversified and focused firms. We also test an additional implication of our hypothesis. We find 
that the benefit of switching industries from a diversified firm accrues almost entirely to workers in high-skill vocations, measured using either pre-closure wage levels or Standard Occupational Classification codes.

Finally, we confirm that redeployment benefits not just the workers, but also the firm. Diversified firms are more likely to retain workers following plant closure when the future opportunities of their remaining segments are high. Moreover, they are more likely to move workers out of industries with declining opportunities. Though they pay higher wages - reflecting the higher outside opportunities of their workers - they also receive higher productivity in return, even measured with respect to payroll.

Our results provide a potential reconciliation of several seemingly conflicting cross-sectional differences between diversified and focused firms. We offer an explanation for higher observed wage levels in diversified firms, even controlling for firm size and individual worker characteristics. Diversified firms cultivate generalist workers with higher interindustry mobility and outside options. Thus, higher wages do not necessarily indicate rent dissipation since workers can also achieve those higher wages outside the firm. In addition, the greater worker mobility in diversified firms may require a higher risk premium, which can reconcile a diversification discount with higher observed productivity.

We also suggest a different interpretation of existing research on the internal capital markets of diversified firms. A substantial body of research suggests that "dark side" theories of internal capital markets dominate empirically: diversified firms appear to engage in socialistic allocation of capital towards struggling divisions. Yet, there is evidence in the literature that diversified firms are more productive than focused firms in the cross-section. Our results provide one possible reconciliation of these results. Diversification can improve productivity through worker skilldevelopment and the ability to redeploy workers internally to their most productive use. Smaller capital reallocations towards industries with good opportunities does not necessarily indicate "socialistic redistribution" of resources in firms with higher labor mobility. An interesting avenue for 
future research is to study the interactions of internal capital and labor allocation in a unified framework.

Finally, the labor-related benefits we identify may provide a motivation for firms to pursue diversification. Variation in the importance of human capital and the opportunities for developing synergistic skills may be an important determinant of the industry configurations that firms choose. However, the importance of this mechanism is difficult to evaluate by comparing the cross-section of diversified and focused firms. In ongoing research, we examine the labor market choices of firms that make diversifying acquisitions. An added advantage of this context is that the acquisition event provides the opportunity for direct measurement of the value consequences of different strategies. Evidence along these lines may help to deepen our understanding of the impact of different organizational structures on the operations of the firm and, ultimately, what factors matter in determining firm boundaries. 


\section{References}

[1] Altonji, J. G. and R. M. Blank, 1999, Race and gender in the labor market in O. Ashenfelter and R. Layard, eds., Handbook of Labor Economics, Volume 3, 3143-3259.

[2] Atkeson, A. and P. J. Kehoe, 2005, Modeling and measuring organization capital, Journal of Political Economy 113, 1026-1053.

[3] Baker, G., M. Gibbs and B. Holmstrom, 1994a, The internal economics of the firm: Evidence from personnel data, Quarterly Journal of Economics 109, 881-919.

[4] Baker, G., M. Gibbs and B. Holmstrom, 1994b, The wage policy of a firm, Quarterly Journal of Economics 109, 921-955.

[5] Berger, P.G. and E. Ofek, 1995, Diversification's effect on firm value, Journal of Financial Economics 37, 39-65.

[6] Campa, J. and S. Kedia, 2002, Explaining the diversification discount, Journal of Finance 57, 1731-1762.

[7] Donangelo, A., 2011, Labor Mobility and the Cross-Section of Expected Returns, Mimeo.

[8] Eisfeldt, A. and D. Papanikolaou, forthcoming, Organization capital and the cross-section of expected returns, Journal of Finance.

[9] Eisfeldt, A. and C. Kuhnen, 2011, CEO turnover in a competitive assignment framework, Mimeo.

[10] Foster, L., J.C. Haltiwanger and C.J. Krizan, 1998, Aggregate productivity growth: Lessons from microeconomic evidence, National Bureau of Economic Research Working Paper No. 6803.

[11] Gabaix, X. and A. Landier, 2008, Why has CEO pay increased so much? Quarterly Journal of Economics 12, 49-100.

[12] Gibbons, R. and L.F. Katz, 1991, Layoffs and lemons, Journal of Labor Economics 9, 351-380.

[13] Giroud, X., 2010, Soft information and investment: Evidence from plant-level data, Mimeo.

[14] Graham, J.R., M.L. Lemmon and J. Wolf, 2002, Does corporate diversification destroy value? Journal of Finance 57, 695-720.

[15] Haltiwanger, J.C., J.I. Lane and J.R. Spletzer, 1999, Productivity differences across employers: The roles of employer size, age and human capital, The American Economic Review 89, 94-98.

[16] Hart, O, 1995, Firms, contracts, and financial structure. London: Oxford University Press.

[17] Hund, J., D. Monk and S. Tice, 2010, Uncertainty about average profitability and the diversification discount, Journal of Financial Economics 96, 463-484.

[18] Jovanovic, B. and R. Moffitt, 1990, An Estimate of a Sectoral Model of Labor Mobility, Journal of Political Economy 98, 827-852. 
[19] Kuppuswamy, V. and B. Villalonga, 2010, Does diversification create value in the presence of external financing constraints? Evidence from the 2007-2009 financial crisis, Working paper, Harvard University.

[20] Lamont, O., 1997, Cash flow and investment: Evidence from internal capital markets, Journal of Finance 52, 83-109.

[21] Lang, L. and R. Stulz, 1994, Tobin's Q, corporate diversification and firm performance, Journal of Political Economy 102, 1248-1280.

[22] Lazear, E., 2009, Firm-specific human capital: A skill weights approach, Journal of Political Economy 117, 914-940.

[23] Lazear, E. and P. Oyer, 2004a, Internal and external labor markets: A personnel economics approach, Labour Economics 11, 527-554.

[24] Lazear, E. and P. Oyer, 2004b, The structure of wages and internal mobility, AER Papers \& Proceedings 94, 212-216.

[25] Lustig, H., C. Syverson and S. Van Nieuwerburgh, 2011, Technological change and the growing inequality in managerial compensation, Journal of Financial Economics 99, 601-627.

[26] Maksimovic, V. and G.M. Phillips, 2002, Do conglomerate firms allocate resources inefficiently across industries? Theory and evidence, Journal of Finance 57, 721-767.

[27] Maksimovic, V. and G.M. Phillips, 2007, Conglomerate firms and internal capital markets in Eckbo, B.E. (ed.), Handbook of Corporate Finance: Empirical Corporate Finance, Elsevier/North-Holland.

[28] Neal, Derek, 1995, Industry-specific human capital: Evidence from displaced workers, Journal of Labor Economics 13, 653-677.

[29] Oi, W.Y. and T.L. Idson, 1999, Firm size and wages in O. Ashenfelter and R. Layard, eds., Handbook of Labor Economics, Volume 3, 2165-2214.

[30] Ozbas, O. and D. S. Scharfstein, 2010, Evidence on the dark side of internal capital markets, Review of Financial Studies 23, 581-599.

[31] Rajan, R., H. Servaes and L. Zingales, 2000, The cost of diversity: The diversification discount and inefficient investment, Journal of Finance 55, 35-80.

[32] Scharfstein, D., and J. Stein, 2000, The dark side of internal capital markets: Divisional Rent-Seeking and Inefficient Investment, Journal of Finance 55, 3537-64

[33] Schoar, A., 2002, Effects of corporate diversification on productivity, Journal of Finance 57, 2379-2403.

[34] Stein, J., 1997, Internal capital markets and the competition for corporate resources, Journal of Finance 52, 111-33

[35] Stein, J., 2003, Agency, information and corporate investment in Constantinides, G., M. Harris, and R. Stulz (eds.) Handbook of the Economics of Finance. Amsterdam: North Holland. 
[36] Tervio, M., 2008, The difference that CEOs make: An assignment model approach, American Economic Review 98, 642-668.

[37] Villalonga, B., 2004, Diversification discount or premium? New evidence from the business information tracking series, Journal of Finance 59, 475-502. 
Table I

\section{Summary Statistics: Plant Level}

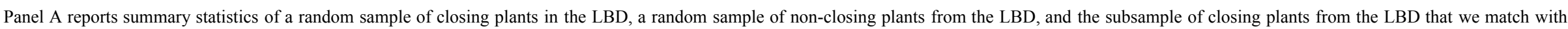

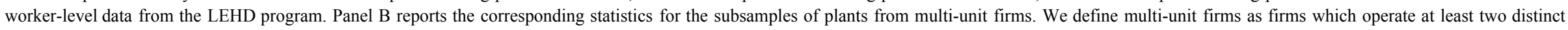
plants. Standard errors are reported in parantheses for continuous variables.

\begin{tabular}{|c|c|c|c|c|c|c|}
\hline & \multicolumn{3}{|c|}{ Panel A: All Firms } & \multicolumn{3}{|c|}{ Panel B: Multi-Unit Firms Only } \\
\hline & $\begin{array}{c}\text { Random Plants in } \\
\text { the LBD } \\
(\mathrm{N}=655,929)\end{array}$ & $\begin{array}{c}\text { Closing Plants in } \\
\text { the LBD } \\
(\mathrm{N}=143,370)\end{array}$ & $\begin{array}{l}\text { Closing Plants in } \\
\text { the LBD Matched } \\
\text { with the LEHD } \\
(\mathrm{N}=12,439)\end{array}$ & $\begin{array}{c}\text { Random Plants in } \\
\text { the LBD } \\
(\mathrm{N}=383,238)\end{array}$ & $\begin{array}{l}\text { Closing Plants in } \\
\text { the LBD } \\
(\mathrm{N}=70,811)\end{array}$ & $\begin{array}{l}\text { Closing Plants in } \\
\text { the LBD Matched } \\
\text { with the LEHD } \\
(\mathrm{N}=1,850)\end{array}$ \\
\hline \multirow[t]{2}{*}{ Plant Employees } & 194 & 188 & 134 & 202 & 187 & 142 \\
\hline & $(514)$ & $(647)$ & $(292)$ & $(473)$ & $(565)$ & $(224)$ \\
\hline \multirow[t]{2}{*}{ Firm Employees } & 25,765 & 22,084 & 4,780 & 43,968 & 44,521 & 31,379 \\
\hline & $(83,464)$ & $(57,124)$ & $(26,992)$ & $(105,480)$ & $(74,912)$ & $(63,789)$ \\
\hline \multirow[t]{2}{*}{ Annual Payroll (\$000's) } & $\$ 6,830$ & $\$ 5,299$ & $\$ 2,333$ & $\$ 7,590$ & $\$ 6,676$ & $\$ 3,703$ \\
\hline & $(\$ 383,230)$ & $(\$ 66,606)$ & $(\$ 6,709)$ & $(\$ 178,102)$ & $(\$ 92,809)$ & $(\$ 9,611)$ \\
\hline$\%$ of Multi-Unit Firms & 0.58 & 0.49 & 0.15 & & & \\
\hline$\%$ of Diversified Firms & 0.42 & 0.39 & 0.10 & 0.71 & 0.79 & 0.69 \\
\hline \multicolumn{7}{|l|}{ Industry Distribution } \\
\hline $\mathrm{SIC}=1$ & 0.05 & 0.04 & 0.09 & 0.02 & 0.02 & \multirow{8}{*}{$\mathrm{N} / \mathrm{A}^{*}$} \\
\hline $\mathrm{SIC}=2$ & 0.08 & 0.08 & 0.08 & 0.09 & 0.08 & \\
\hline $\mathrm{SIC}=3$ & 0.10 & 0.08 & 0.07 & 0.10 & 0.09 & \\
\hline $\mathrm{SIC}=4$ & 0.06 & 0.07 & 0.05 & 0.08 & 0.08 & \\
\hline $\mathrm{SIC}=5$ & 0.29 & 0.27 & 0.28 & 0.36 & 0.30 & \\
\hline $\mathrm{SIC}=6$ & 0.06 & 0.09 & 0.04 & 0.07 & 0.10 & \\
\hline $\mathrm{SIC}=7$ & 0.13 & 0.19 & 0.24 & 0.13 & 0.18 & \\
\hline $\mathrm{SIC}=8$ & 0.21 & 0.16 & 0.13 & 0.15 & 0.13 & \\
\hline \multicolumn{7}{|l|}{ Geographic Distribution } \\
\hline LEHD State & 0.55 & 0.57 & . & 0.55 & 0.57 & . \\
\hline Region $=\mathrm{NE}$ & 0.22 & 0.22 & 0.08 & 0.21 & 0.22 & 0.09 \\
\hline Region $=\mathrm{MW}$ & 0.25 & 0.21 & 0.16 & 0.25 & 0.22 & 0.18 \\
\hline Region $=\mathrm{S}$ & 0.23 & 0.24 & 0.23 & 0.24 & 0.24 & 0.26 \\
\hline Region $=\mathrm{SW}$ & 0.12 & 0.13 & 0.19 & 0.12 & 0.12 & 0.19 \\
\hline Region $=\mathrm{W}$ & 0.14 & 0.16 & 0.29 & 0.14 & 0.15 & 0.22 \\
\hline Region $=$ RM & 0.04 & 0.03 & 0.05 & 0.04 & 0.03 & 0.06 \\
\hline \multicolumn{7}{|l|}{ Yearly Distribution } \\
\hline Year $=1994$ & 0.10 & 0.08 & 0.08 & 0.10 & 0.07 & 0.05 \\
\hline Year $=1995$ & 0.11 & 0.08 & 0.10 & 0.10 & 0.08 & 0.07 \\
\hline Year $=1996$ & 0.11 & 0.11 & 0.12 & 0.11 & 0.11 & 0.13 \\
\hline Year $=1997$ & 0.11 & 0.10 & 0.09 & 0.11 & 0.10 & 0.07 \\
\hline Year $=1998$ & 0.11 & 0.11 & 0.13 & 0.12 & 0.11 & 0.12 \\
\hline Year $=1999$ & 0.12 & 0.12 & 0.12 & 0.12 & 0.14 & 0.10 \\
\hline Year $=2000$ & 0.12 & 0.12 & 0.14 & 0.12 & 0.13 & 0.22 \\
\hline Year $=2001$ & 0.12 & 0.21 & 0.14 & 0.12 & 0.17 & 0.17 \\
\hline
\end{tabular}

*Some industries have a limited number of firms. Due to potential disclosure risk, we cannot report the industry distribution for this subsample. 
Table II

Summary Statistics: Worker Level

Panel A reports summary statistics for a random sample of workers from the LEHD data. Panel B reports summary statistics for workers matched to closing plants in the LBD. We report statistics for the overall sample and for the subsmples of worker from single-unit firms, multi-unit focused firms, and multi-unit diversified firms. We define multi-unit firms as firms which operate at least two distinct plants and diversified firms as firms which operate in more than one two-digit SIC code. Standard errors are reported in parantheses for continuous variables.

Panel A: Random Workers from the LEHD data

\begin{tabular}{lcccc}
\hline & $\begin{array}{c}\text { Full Sample } \\
(\mathrm{N}=251,440)\end{array}$ & $\begin{array}{c}\text { Single-Unit Firms } \\
(\mathrm{N}=63,173)\end{array}$ & $\begin{array}{c}\text { Multi-Unit Focused } \\
\text { Firms }(\mathrm{N}=34,042)\end{array}$ & $\begin{array}{c}\text { Multi-Unit Diversified } \\
\text { Firms (N=154,225) }\end{array}$ \\
\hline Annual Wage & $\$ 34,999$ & $\$ 30,613$ & $\$ 33,527$ & $\$ 37,121$ \\
& $(92,402)$ & $(64,364)$ & $(93,173)$ & $(101,461)$ \\
Age & 41.33 & 42.59 & 40.06 & 41.09 \\
& $(11.10)$ & $(11.28)$ & $(11.30)$ & $(10.94)$ \\
Tenure (in yrs) & 3.36 & 3.49 & 3.17 & 3.34 \\
& $(2.61)$ & $(2.68)$ & $(2.52)$ & $(2.59)$ \\
Education (in yrs) & 13.79 & 13.89 & 13.73 & $(2.59)$ \\
& $(2.60)$ & $(2.60)$ & $(2.63)$ & 0.43 \\
\% of Female & 0.46 & 0.51 & 0.49 & 0.10 \\
Race = Black & 0.10 & 0.10 & 0.10 & 0.04 \\
Race = Asian & 0.04 & 0.03 & 0.04 & 0.08 \\
Race = Hispanic & 0.09 & 0.10 & 0.09 & 0.05 \\
Race = Other & 0.05 & 0.05 & 0.06 & 0.14 \\
\% of Foreigner & 0.14 & 0.14 & 0.15 & \\
\hline
\end{tabular}

Panel B: Workers from the LEHD data matched to Closing Plants from the LBD

\begin{tabular}{lcccc}
\hline & $\begin{array}{c}\text { Full Sample } \\
(\mathrm{N}=461,449)\end{array}$ & $\begin{array}{c}\text { Single-Unit Firms } \\
(\mathrm{N}=395,338)\end{array}$ & $\begin{array}{c}\text { Multi-Unit Focused } \\
\text { Firms }(\mathrm{N}=15,947)\end{array}$ & $\begin{array}{c}\text { Multi-Unit Diversified } \\
\text { Firms }(\mathrm{N}=50,137)\end{array}$ \\
\hline Annual Wage & $\$ 29,933$ & $\$ 29,751$ & $\$ 28,642$ & $\$ 31,781$ \\
& $(54,517)$ & $(56,278)$ & $(33,666)$ & $(44,897)$ \\
Age & 39.68 & 39.53 & 39.59 & 40.89 \\
& $(11.43)$ & $(11.47)$ & $(11.53)$ & $(10.99)$ \\
Tenure (in yrs) & 2.57 & 2.52 & 2.69 & 2.96 \\
& $(2.20)$ & $(2.18)$ & $(2.51)$ & $(2.17)$ \\
Education (in yrs) & 13.66 & 13.64 & 13.64 & 13.82 \\
& $(2.66)$ & $(2.67)$ & $(2.60)$ & 0.41 \\
\% of Female & 0.41 & 0.41 & 0.42 & 0.11 \\
Race = Black & 0.10 & 0.10 & 0.13 & 0.04 \\
Race = Asian & 0.04 & 0.04 & 0.05 & 0.09 \\
Race = Hispanic & 0.12 & 0.13 & 0.10 & 0.05 \\
Race = Other & 0.06 & 0.06 & 0.05 & 0.15 \\
\% of Foreigner & 0.19 & 0.19 & 0.18 &
\end{tabular}


Table III

\section{Wage Changes: "Related" and "Unrelated" Industry Changes}

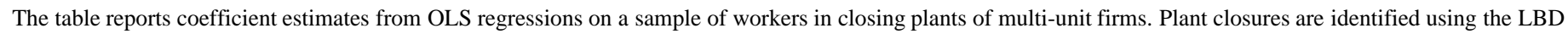

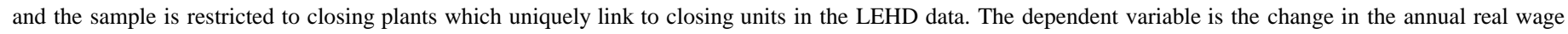

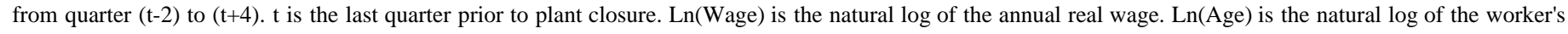

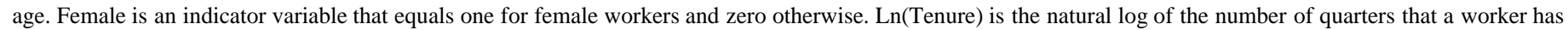

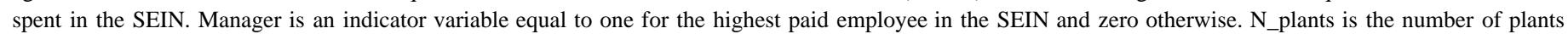

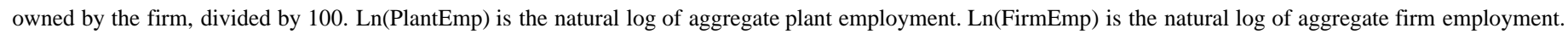

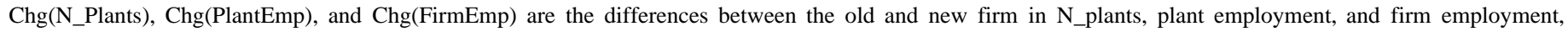

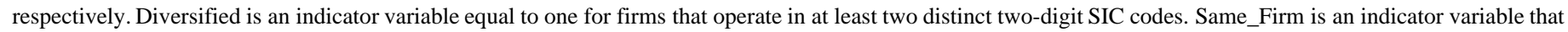

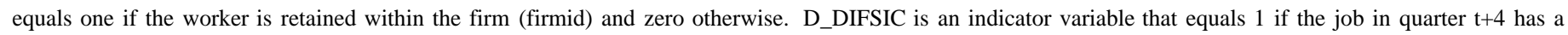

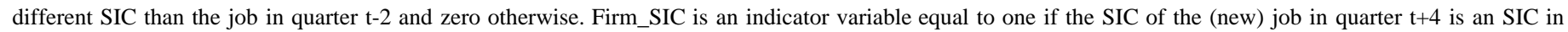

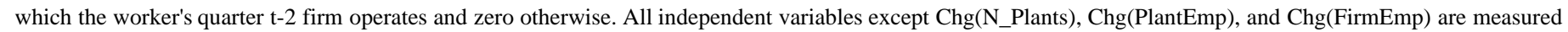

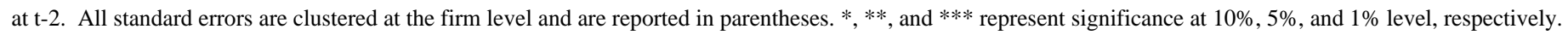

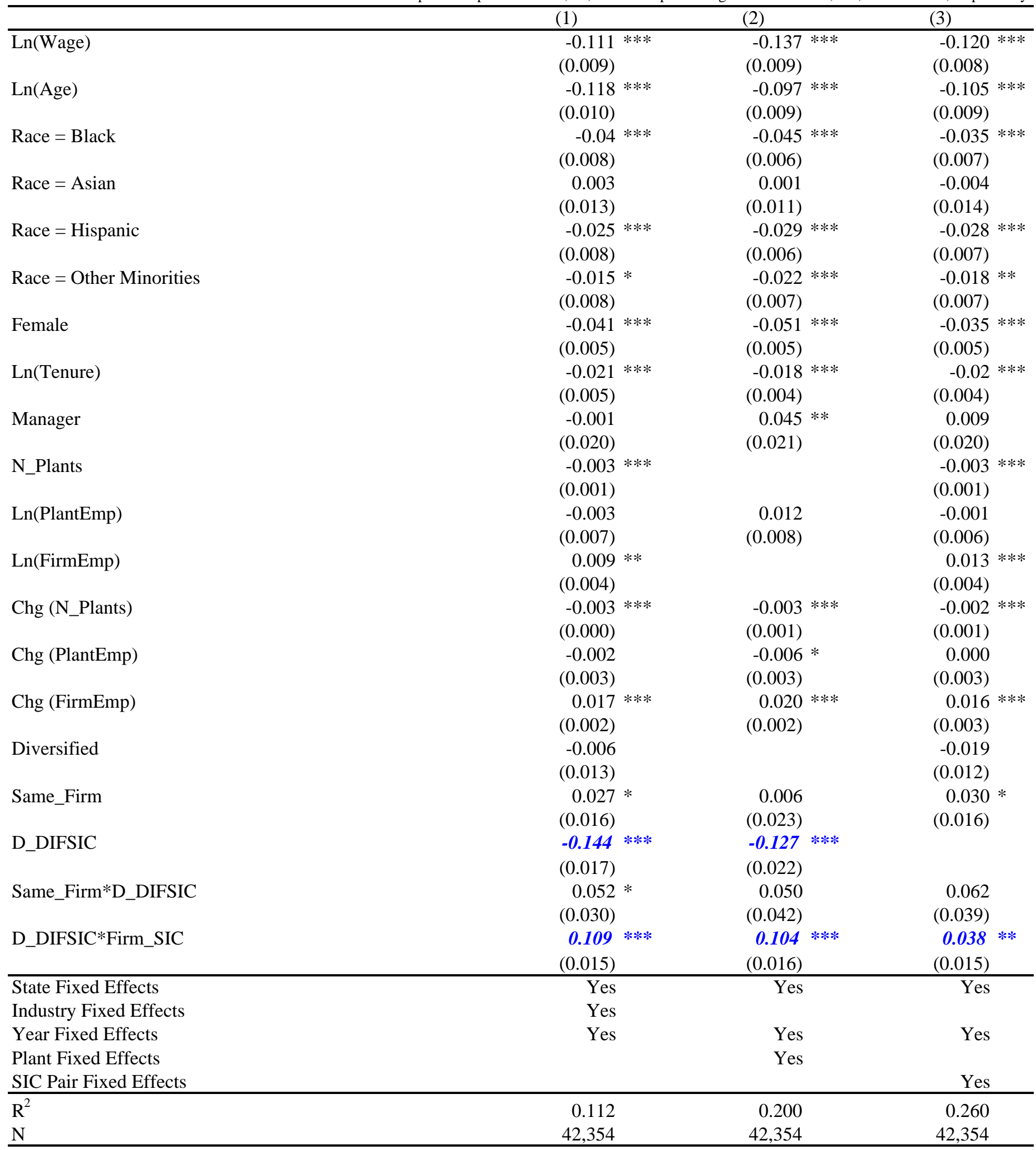


Table IV

Summary Statistics: Displaced Industry-Switchers from Diversified Plants

The sample consists of workers displaced from a plant owned by a diversified firm who take a new job in a different firm operating in a different industry. Plant closures are identified using the LBD and the sample is restricted to closing plants which uniquely link to closing units in the LEHD data. We report the mean of group means for each characteristic, where groups are defined by the industry pair between which workers switch (i.e. there is one group for each pair of 2-digit SIC codes between which any sample workers switch). Foreign is an indicator for foreign workers. Native is an indicator for workers who were born in the state in which their closing plant operated. Ln(Wage) is the natural log of the annual real wage. Prior Industry Experience is an indicator for workers who worked in their new, post-diplacement industry prior to taking a job in the diverisifed firm from which they were displaced. Firm Employment, Plant Employment, and Nplants measure firm employment, plant employment and the number of plants for the diversified firm from which the worker was displaced. Standard errors are clustered at the firm level.

\begin{tabular}{lccc}
\hline & $\begin{array}{c}\text { Prior Firm } \\
\text { Operates in New } \\
\text { Industry }\end{array}$ & $\begin{array}{c}\text { Prior Firm Does } \\
\text { Not Operate in } \\
\text { New Industry }\end{array}$ & $\begin{array}{c}\text { Difference } \\
\text { p-value }\end{array}$ \\
\hline Worker Characteristics & & & \\
Race = Black & 0.081 & 0.079 & 0.894 \\
Race = Asian & 0.039 & 0.046 & 0.525 \\
Race = Hispanic & 0.086 & 0.121 & 0.066 \\
Race = Other Minorities & 0.058 & 0.048 & 0.405 \\
Foreign & 0.132 & 0.163 & 0.140 \\
Native & 0.479 & 0.487 & 0.803 \\
Tenure (in yrs) & 2.507 & 2.507 & 0.997 \\
ln(Wage) & 10.131 & 10.075 & 0.152 \\
Prior Industry Experience & 0.140 & 0.119 & 0.294 \\
& & & \\
Firm Characteristics & & & 0.000 \\
Firm Employment & $33,571.436$ & $10,432.038$ & 0.748 \\
Plant Employment & 269.684 & 281.011 & 0.005 \\
Nplants & 455.1 & 177.9 & \\
\hline
\end{tabular}




\section{Table V}

\section{Alternative Explanations}

The table reports estimated coefficents from OLS regressions on a sample of workers in closing plants of multi-unit firms. Plant closures are identified using the LBD and the sample is restricted to closing plants which uniquely link to closing units in the LEHD data. The dependent variable is the change in the annual real wage from quarter ( $\mathrm{t}-2)$ to $(\mathrm{t}+4) . \mathrm{t}$ is the last quarter prior to plant closure. Demographic and firm controls are indicator variables for female, black, Asian, Hispanic, and other minority workers; Ln(Wage); Ln(Age); Ln(Tenure); an indicator for the unit manager; N_plants; Ln(PlantEmp); Ln(FirmEmp); Chg(N_Plants); Chg(PlantEmp); and Chg(FirmEmp). See Table III for additional details on the definitions of these variables. Diversified is an indicator variable equal to one for firms that operate in at least two distinct two-digit SIC codes. Same_Firm is an indicator variable that equals one if the worker is retained within the firm (firmid) and zero otherwise. D_DIFSIC is an indicator variable that equals 1 if the job in quarter $\mathrm{t}+4$ has a different SIC than the job in quarter $\mathrm{t}-2$ and zero otherwise. Firm_SIC is an indicator variable equal to one if the SIC of the (new) job in quarter $\mathrm{t}+4$ is an SIC in which the worker's quarter t-2 firm operates and zero otherwise. Distance is the number of miles from the center of the county of the worker's t-2 job to the center of the county of the worker's $t+4$ job. Ln(\# of Firms in CT \& SIC2) is the natural log of the number of plants operating in the county and 2-digit SIC of the closing plant; Ln(\# of Firms in CT) is the natural log of the number of plants operating in the county of the closing plant; $\mathrm{Ln}\left(\#\right.$ of Firms in CT \& SIC2 $\left.\mathrm{t}_{\mathrm{t}+4}\right)$ is the natural log of the number of plants operating in the county of the closing plant in the 2-digit SIC code in which the workers works in quarter $t+4$. Prior Experience is an indicator variable equal to one if the worker changed industries between quarters $\mathrm{t}-2$ and $\mathrm{t}+4$, but had experience working in the new industry prior to joining the $\mathrm{t}-2$ employer. All independent variables except Chg(N_Plants), Chg(PlantEmp), and Chg(FirmEmp) are measured at t-2. All standard errors are clustered at the firm level and are reported in parentheses. *,**, and *** represent significance at $10 \%, 5 \%$, and $1 \%$ level, respectively.

\begin{tabular}{|c|c|c|c|}
\hline & $\begin{array}{c}\text { Distance Between } \\
\text { Jobs } \\
(1)\end{array}$ & $\begin{array}{c}\text { Local } \\
\text { Opportunities } \\
(2)\end{array}$ & $\begin{array}{c}\begin{array}{c}\text { Prior Industry } \\
\text { Experience }\end{array} \\
\text { (3) }\end{array}$ \\
\hline Diversified & -0.019 & -0.018 & -0.019 \\
\hline & $(0.012)$ & $(0.011)$ & $(0.012)$ \\
\hline Same_Firm & 0.029 & -0.160 & $0.031 *$ \\
\hline & $(0.018)$ & $(0.129)$ & $(0.016)$ \\
\hline Same_Firm * D_DIFSIC & $\begin{array}{c}0.068 * \\
(0.040)\end{array}$ & $\begin{array}{r}0.035 \\
(0.035)\end{array}$ & $\begin{array}{c}0.066 * \\
(0.036)\end{array}$ \\
\hline D_DIFSIC * Firm_SIC & $\begin{array}{l}0.037 \text { ** } \\
(0.015)\end{array}$ & $\begin{array}{l}0.038 \\
(0.015)\end{array}$ & $\begin{array}{l}0.039 \\
(0.016)\end{array}$ \\
\hline D_DIFSIC * Firm_SIC * Prior Exp. & & & $\begin{array}{r}-0.010 \\
(0.023)\end{array}$ \\
\hline Distance & $\begin{array}{l}-0.005 * \\
(0.003)\end{array}$ & & \\
\hline Distance * D_DIFSIC & $\begin{array}{c}0.0077^{* *} \\
(0.003)\end{array}$ & & \\
\hline Distance * Same_Firm & $\begin{array}{l}(0.003) \\
(0.007)\end{array}$ & & \\
\hline Ln(\# of Firms in CT \& SIC2) & & $\begin{array}{r}-0.009 \\
(0.015)\end{array}$ & \\
\hline $\operatorname{Ln}(\#$ of Firms in CT) & & $\begin{array}{r}-0.002 \\
(0.011)\end{array}$ & \\
\hline $\mathrm{Ln}\left(\#\right.$ of Firms in CT \& $\left.\mathrm{SIC}_{\mathrm{t}+4}\right)$ & & $\begin{array}{r}0.011 \\
(0.011)\end{array}$ & \\
\hline $\operatorname{Ln}(\#$ of Firms in CT \& SIC2) * D_DIFSIC & & $\begin{array}{r}0.027 \\
(0.020)\end{array}$ & \\
\hline $\operatorname{Ln}(\#$ of Firms in CT $) *$ D_DIFSIC & & $\begin{array}{r}-0.014 \\
(0.020)\end{array}$ & \\
\hline $\operatorname{Ln}(\#$ of Firms in CT \& SIC2) * Same_Firm & & $\begin{array}{r}-0.028 \\
(0.020)\end{array}$ & \\
\hline $\operatorname{Ln}(\#$ of Firms in CT $) *$ Same_Firm & & $\begin{array}{r}0.022 \\
(0.015)\end{array}$ & \\
\hline $\operatorname{Ln}\left(\#\right.$ of Firms in CT \& $\left.\mathrm{SIC}_{\mathrm{t}+4}\right) *$ Same_Firm & & $\begin{array}{r}0.024 \\
(0.021)\end{array}$ & \\
\hline Prior Experience & & & $\begin{array}{r}-0.013 \\
(0.014)\end{array}$ \\
\hline Prior Experience * Same_Firm & & & $\begin{array}{r}-0.010 \\
(0.046) \\
\end{array}$ \\
\hline Demographic and Firm Controls & Yes & Yes & Yes \\
\hline State Fixed Effects & Yes & Yes & Yes \\
\hline Year Fixed Effects & Yes & Yes & Yes \\
\hline SIC Pair Fixed Effects & Yes & Yes & Yes \\
\hline $\mathrm{R}^{2}$ & 0.261 & 0.262 & 0.260 \\
\hline $\mathrm{N}$ & 42,354 & 42,354 & 42,354 \\
\hline
\end{tabular}




\section{Table VI \\ Worker Skill}

The table reports estimated coefficents from OLS regressions on a sample of workers in closing plants of multi-unit firms. Plant closures are identified using the LBD and the sample is restricted to closing plants which uniquely link to closing units in the LEHD data. The dependent variable is the change in the annual real wage from quarter ( $t-2)$ to $(\mathrm{t}+4) . \mathrm{t}$ is the last quarter prior to plant closure. Demographic and firm controls are indicator variables for female, black, Asian, Hispanic, and other minority workers; Ln(Wage); Ln(Age); Ln(Tenure); an indicator for the unit manager; N_plants; Ln(PlantEmp); Ln(FirmEmp); Chg(N_Plants); Chg(PlantEmp); and Chg(FirmEmp). See Table III for additional details on the definitions of these variables. Diversified is an indicator variable equal to one for firms that operate in at least two distinct two-digit SIC codes. Same Firm is an indicator variable that equals one if the worker is retained within the firm (firmid) and zero otherwise. D DIFSIC is an indicator variable that equals 1 if the job in quarter $\mathrm{t}+4$ has a different SIC than the job in quarter $\mathrm{t}-2$ and zero otherwise. Firm_SIC is an indicator variable equal to one if the SIC of the (new) job in quarter $\mathrm{t}+4$ is an SIC in which the worker's quarter $\mathrm{t}-2$ firm operates and zero otherwise. $\leq$ Wage $<\mathrm{y}$ are indicator variables equal to 1 if the worker's real annual wage in quarter $\mathrm{t}-2$ falls in the indicated range. High_Skill is an indicator variable equal to one if the percentage of workers in the 2-digit SIC in occupations with 2-digit SOC codes less than 29 exceeds the median. Low Skill is the complement of High Skill. All independent variables except Chg(N Plants), Chg(PlantEmp), and Chg(FirmEmp) are measured at $\mathrm{t}-2$. All standard errors are clustered at the firm level and are reported in parentheses. $*, * *$, and $* * *$ represent significance at $10 \%, 5 \%$, and $1 \%$ level, respectively.

\begin{tabular}{|c|c|c|c|c|c|c|c|c|}
\hline & \multicolumn{5}{|c|}{ Panel A. Wage Splits } & \multicolumn{3}{|c|}{ Panel B. Standard Occupational Codes } \\
\hline & \multicolumn{2}{|l|}{ (1) } & \multicolumn{2}{|c|}{$(2)$} & (3) & $(4)$ & $(5)$ & $(6)$ \\
\hline \multirow[t]{2}{*}{ Diversified } & -0.009 & & & & $-0.022 *$ & -0.006 & & -0.019 \\
\hline & $(0.012)$ & & & & $(0.012)$ & $(0.013)$ & & $(0.012)$ \\
\hline \multirow[t]{2}{*}{ Same_Firm } & 0.024 & & 0.007 & & 0.026 & $0.028 *$ & 0.006 & $0.030 *$ \\
\hline & $(0.015)$ & & $(0.023)$ & & $(0.016)$ & $(0.016)$ & $(0.023)$ & $(0.016)$ \\
\hline \multirow[t]{2}{*}{ Same_Firm $*$ D_DIFSIC } & 0.050 & $*$ & 0.048 & & 0.059 & $0.050 *$ & 0.048 & 0.058 \\
\hline & $(0.030)$ & & $(0.041)$ & & $(0.038)$ & $(0.030)$ & $(0.041)$ & $(0.039)$ \\
\hline \multirow[t]{2}{*}{ D_DIFSIC $*($ Wage $<25 \mathrm{~K})$} & -0.128 & $* * *$ & -0.103 & $* * *$ & 0.024 & & & \\
\hline & $(0.013)$ & & $(0.015)$ & & $(0.065)$ & & & \\
\hline \multirow[t]{2}{*}{ D_DIFSIC $*(25 \mathrm{~K} \leq$ Wage $<50 \mathrm{~K})$} & -0.163 & $* * *$ & -0.147 & $* * *$ & 0.000 & & & \\
\hline & $(0.027)$ & & $(0.032)$ & & $(0.065)$ & & & \\
\hline \multirow[t]{2}{*}{ D_DIFSIC $*(50 \mathrm{~K} \leq$ Wage $<100 \mathrm{~K})$} & -0.134 & $* * *$ & -0.144 & $* * *$ & -0.021 & & & \\
\hline & $(0.022)$ & & $(0.028)$ & & $(0.068)$ & & & \\
\hline \multirow{2}{*}{ D_DIFSIC $*($ Wage $\geq 100 \mathrm{~K})$} & -0.134 & $* *$ & -0.181 & $* * *$ & & & & \\
\hline & $(0.063)$ & & $(0.067)$ & & & & & \\
\hline \multirow[t]{2}{*}{ D_DIFSIC $*($ Wage $<25 \mathrm{~K}) *$ Firm_SIC } & 0.097 & $* * *$ & 0.083 & $* * *$ & 0.017 & & & \\
\hline & $(0.017)$ & & $(0.018)$ & & $(0.017)$ & & & \\
\hline \multirow[t]{2}{*}{ D_DIFSIC $*(25 \mathrm{~K} \leq$ Wage $<50 \mathrm{~K}) *$ Firm_SIC } & 0.117 & $* * *$ & 0.117 & $* * *$ & $0.041 *$ & & & \\
\hline & $(0.025)$ & & $(0.024)$ & & $(0.022)$ & & & \\
\hline \multirow[t]{2}{*}{ D_DIFSIC $*(50 \mathrm{~K} \leq$ Wage $<100 \mathrm{~K}) *$ Firm_SIC } & 0.094 & $* * *$ & 0.127 & $* * *$ & $0.068 * *$ & & & \\
\hline & $(0.028)$ & & $(0.025)$ & & $(0.031)$ & & & \\
\hline \multirow[t]{2}{*}{ D_DIFSIC $*($ Wage $\geq 100 \mathrm{~K}) *$ Firm_SIC } & 0.159 & $* *$ & 0.210 & $* * *$ & 0.109 & & & \\
\hline & $(0.075)$ & & $(0.077)$ & & $(0.082)$ & & & \\
\hline \multirow[t]{2}{*}{ D_DIFSIC } & & & & & & $-0.146 * * *$ & $-0.121 * * *$ & \\
\hline & & & & & & $(0.015)$ & $(0.013)$ & \\
\hline \multirow[t]{2}{*}{ High_Skill $*$ D_DIFSIC } & & & & & & 0.004 & -0.010 & \\
\hline & & & & & & $(0.026)$ & $(0.034)$ & \\
\hline \multirow[t]{2}{*}{ High_Skill $*$ D_DIFSIC $*$ Firm_SIC } & & & & & & $0.117 * * *$ & $0.114 * * *$ & $0.055 * * *$ \\
\hline & & & & & & $(0.021)$ & $(0.022)$ & $(0.019)$ \\
\hline \multirow[t]{2}{*}{ Low_Skill $*$ D_DIFSIC $*$ Firm_SIC } & & & & & & $0.091 * * *$ & $0.084 * * *$ & -0.002 \\
\hline & & & & & & $(0.022)$ & $(0.022)$ & $(0.029)$ \\
\hline Demographic and Firm Controls & Yes & & Yes & & Yes & Yes & Yes & Yes \\
\hline State Fixed Effects & Yes & & Yes & & Yes & Yes & Yes & Yes \\
\hline Industry Fixed Effects & Yes & & & & & Yes & & \\
\hline Year Fixed Effects & Yes & & Yes & & Yes & Yes & Yes & Yes \\
\hline Plant Fixed Effects & & & Yes & & & & Yes & \\
\hline SIC Pair Fixed Effects & & & & & Yes & & & Yes \\
\hline $\mathrm{R}^{2}$ & 0.112 & & 0.197 & & 0.253 & 0.118 & 0.205 & 0.260 \\
\hline $\mathrm{N}$ & 42,354 & & 42,354 & & 42,354 & 42,354 & 42,354 & 42,354 \\
\hline
\end{tabular}


Table VII

Labor Redeployment

In Columns (1) - (4) are on the sample of workers displaced from closing plants of diversified firms; in Column (5), the sample is all workers displaced from closing plants. Plant closures are identified using the LBD and the sample is restricted to closing plants which uniquely link to the LEHD data. Columns (1) - (3) are probit regressions with coefficient estimates reported as the marginal effect at the mean. Column (4) is the second stage of a Heckman selection model with the regressions in Column (1) serving as the first stage. The second stage is estimated as a linear probability model. Column (5) is a logit regression with coefficient estimates reported as log odds ratios. The dependent variable is indicated in the column header. Same Firm equals one if the worker remains in the same firm after the plant closure and zero otherwise. Same Industry equals one if the new job in quarter $\mathrm{t}+4$ is in a different two-digit SIC from the lost job. Ln(Wage) is the natural log of the annualized wage. Ln(Age) is the natural log of the worker's age. Female is an indicator variable that equals one for female workers and zero otherwise. Ln(Tenure) is the natural log of the number of quarters that a worker has spent in the SEIN. Manager is an indicator variable equal to one for the highest paid employee in the SEIN and zero otherwise. N_plants is the number of plants owned by the firm, divided by 100. Ln(PlantEmp) is the natural log of aggregate plant employment. Ln(FirmEmp) is the natural log of aggregate firm employment. Diversified is an indicator variable equal to one for firms that operate in at least two distinct two-digit SIC codes. Chg Q is the change in industry-median Tobin's q over the two years following plant closure. Firm_Q is the payroll weighted average of industry-median q for the remaining plants of the firm. Ln(\# of Firms in CT \& SIC2) is the natural log of the number of plants that operate in the same 2-digit SIC code and county as the closing plant. Native to State is an indicator variable which equals one if the worker was born in the state in which the closing plant is located. High- (Low-) skill workers are workers whose pre-closure wage is above the mean wage in the closing plant. Standard errors in Column 5 are clustered at the firm level and are reported in parentheses. *, **, and *** represent significance at $10 \%, 5 \%$, and $1 \%$ level, respectively.

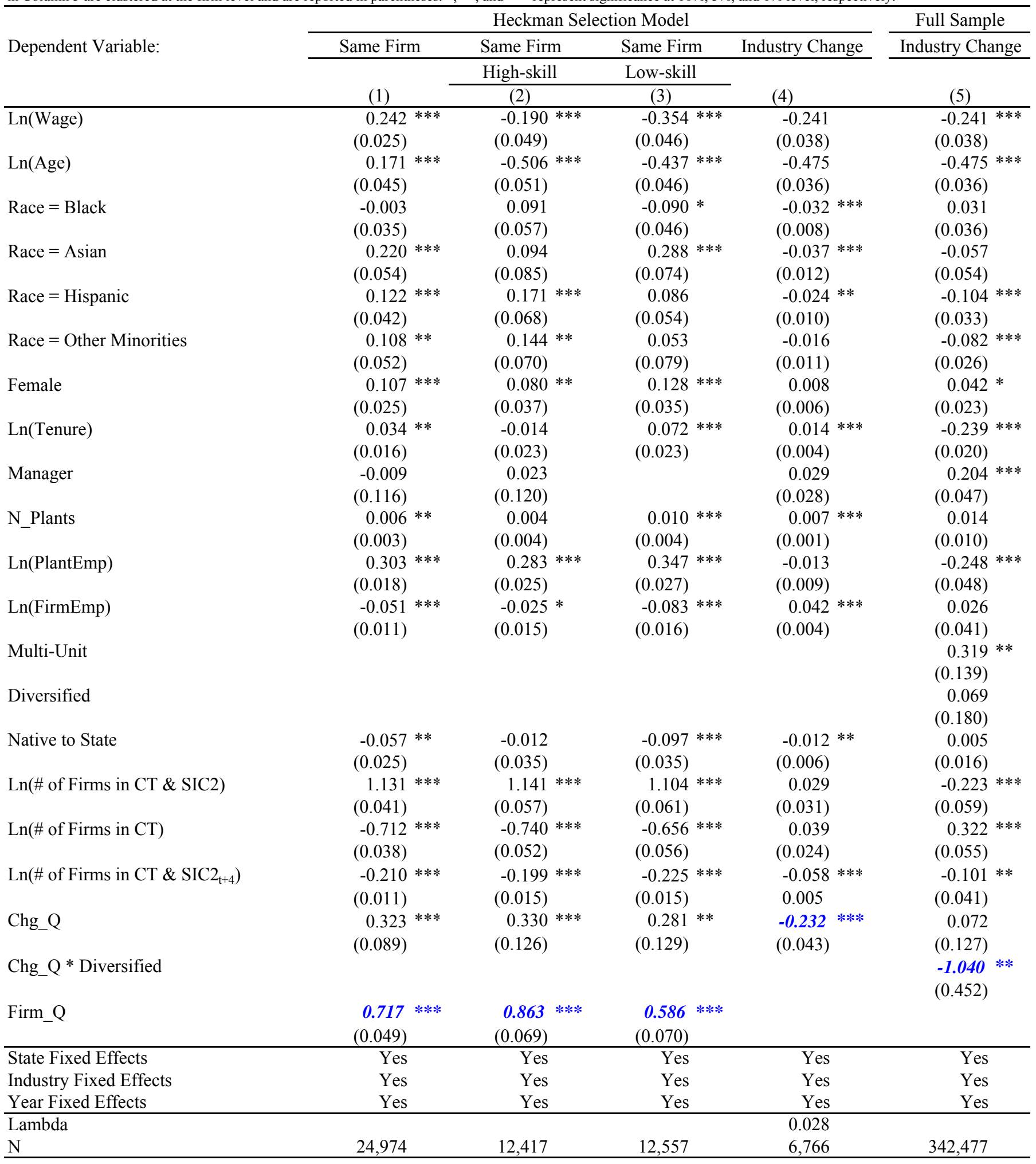




\section{Table VIII}

\section{Wages in Focused and Diversified Firms}

OLS regressions on a random sample of workers from the LEHD data. The dependent variable is the natural log of the annual real wage. $\mathrm{Ln}$ (Age) is the natural log of the worker's age. Female is an indicator variable that equals one for female workers and zero otherwise. Ln(Tenure) is the natural log of the number of quarters that a worker has spent in the SEIN. Manager is an indicator variable equal to one for the highest paid employee in the SEIN and zero otherwise. N_plants is the number of plants owned by the firm, divided by 100. Ln(PlantEmp) is the natural log of aggregate SEIN employment. Ln(FirmEmp) is the natural log of aggregate firm employment. Diversified is an indicator variable equal to one for firms that operate in at least two distinct two-digit SIC codes. \% Emp. in High Skill Ind. is the percentage of firm employment in 2-digit SIC codes in which the percentage of workers with 2-digit SOC codes less than 29 exceeds the median. All standard erros are clustered at the firm level and are reported in parentheses. *, **, and *** represent significance at $10 \%$, 5\%, and $1 \%$ level, respectively.

\begin{tabular}{|c|c|c|c|}
\hline & $(1)$ & (2) & \\
\hline \multirow[t]{2}{*}{$\overline{\text { Ln(Age) }}$} & $0.352 * * *$ & 0.348 & $* * *$ \\
\hline & $(0.009)$ & 0.009 & \\
\hline \multirow[t]{2}{*}{ Race $=$ Black } & $-0.221 * * *$ & -0.219 & $* * *$ \\
\hline & $(0.005)$ & $(0.005)$ & \\
\hline \multirow[t]{2}{*}{ Race $=$ Asian } & $-0.068 * * *$ & -0.069 & $* * *$ \\
\hline & $(0.009)$ & $(0.009)$ & \\
\hline \multirow[t]{2}{*}{ Race $=$ Hispanic } & $-0.314 * * *$ & -0.309 & $* * *$ \\
\hline & $(0.006)$ & $(0.006)$ & \\
\hline \multirow[t]{2}{*}{ Race $=$ Others } & $-0.044 * * *$ & -0.044 & $* * *$ \\
\hline & $(0.007)$ & $(0.007)$ & \\
\hline \multirow[t]{2}{*}{ Female } & $-0.289 * * *$ & -0.289 & $* * *$ \\
\hline & $(0.005)$ & $(0.005)$ & \\
\hline \multirow[t]{2}{*}{ Ln(Tenure) } & $0.090 * * *$ & 0.091 & $* * *$ \\
\hline & $(0.003)$ & $(0.003)$ & \\
\hline \multirow[t]{2}{*}{ Manager } & 1.113 *** & 1.115 & $* * *$ \\
\hline & $(0.027)$ & $(0.027)$ & \\
\hline \multirow[t]{2}{*}{ N_Plants } & $-0.001 * *$ & -0.001 & $*$ \\
\hline & $(0.001)$ & $(0.001)$ & \\
\hline \multirow[t]{2}{*}{ Ln(PlantEmp) } & $0.016 * * *$ & 0.019 & $* * *$ \\
\hline & $(0.003)$ & $(0.003)$ & \\
\hline \multirow[t]{2}{*}{ Ln(FirmEmp) } & $0.026 * * *$ & 0.022 & $* * *$ \\
\hline & $(0.003)$ & $(0.003)$ & \\
\hline \multirow[t]{2}{*}{ Multi-Unit } & 0.006 & -0.002 & \\
\hline & $(0.008)$ & $(0.008)$ & \\
\hline \multirow[t]{2}{*}{ Diversified } & $0.022 * *$ & -0.017 & $*$ \\
\hline & $(0.009)$ & $(0.010)$ & \\
\hline \multirow[t]{2}{*}{ \% Emp. in High Skill Ind. } & & 0.088 & $* * *$ \\
\hline & & $(0.013)$ & \\
\hline \multirow[t]{2}{*}{ (\% Emp. High Skill)*(Div.) } & & 0.074 & $* * *$ \\
\hline & & $(0.014)$ & \\
\hline State Fixed Effects & Yes & Yes & \\
\hline Industry Fixed Effects & Yes & Yes & \\
\hline Year Fixed Effects & Yes & Yes & \\
\hline $\mathrm{R}^{2}$ & 0.324 & 0.327 & \\
\hline $\mathrm{N}$ & 251,440 & 251,440 & \\
\hline
\end{tabular}




\section{Productivity and Cash Flows in Diversified Firms}

The sample consists of all diversified firms for which we can match each individual segment (defined by 2-digit SIC codes) to a focused firm benchmark or which has a segment with a one-digit SIC of 0 (agriculture), 4 (utilities), 6 (financials) or 9 (public sector). For each segment, we select matched focused firms based on 2-digit industry, year, size and age. The cutoffs to define size groups are $<20,20-50,50-100,100-250,250-500$, and $>500$ employees, respectively; and the cutoffs to define age groups are $<5,5-10,10-15,15-20$ and $>20$ years, respectively. In Panel A (B), we use the median sales employment (payroll) ratio of the matched group multiplied by the actual employment of the segment to compute the predicted sales for the segment. Total predicted sales for a diversified firm is the sum of predicted sales of all segments. The dependent variable is the difference between actual sales and predicted sales in natural logarithms. \% Emp. in High Skill Ind. is the percentage of firm employment in 2-digit SIC codes in which the percentage of workers with 2-digit SOC codes less than 29 exceeds the median. The standard errors are clustered by year and are reported in parentheses. *, **, and *** represent significance at $10 \%$, $5 \%$, and $1 \%$ level, respectively.

\begin{tabular}{|c|c|c|c|c|}
\hline & \multicolumn{2}{|c|}{ Panel A. Sales/Employment } & \multicolumn{2}{|c|}{ Panel B. Sales/Payroll } \\
\hline & $(1)$ & $(2)$ & $(3)$ & (4) \\
\hline \multirow[t]{2}{*}{$\overline{\text { Ln(Firm Age) }}$} & & $-0.044 * * *$ & & 0.005 \\
\hline & & $(0.013)$ & & $(0.009)$ \\
\hline \multirow[t]{2}{*}{ Ln(FirmEmp) } & & $0.027 * * *$ & & -0.005 \\
\hline & & $(0.002)$ & & $(0.003)$ \\
\hline \multirow[t]{2}{*}{ \% Emp. in High Skill Ind. } & & $0.205 * * *$ & & $0.013 * *$ \\
\hline & & $(0.012)$ & & $(0.004)$ \\
\hline \multirow[t]{2}{*}{ Constant } & $0.091 * * *$ & -0.007 & $0.109 * * *$ & $0.106 * *$ \\
\hline & $(0.004)$ & $(0.038)$ & $(0.003)$ & $(0.034)$ \\
\hline Year Fixed Effects & Yes & Yes & Yes & Yes \\
\hline $\mathrm{R}^{2}$ & & 0.017 & & 0.001 \\
\hline $\mathrm{N}$ & 35,042 & 35,042 & 35,042 & 35,042 \\
\hline
\end{tabular}


Table X

\section{Worker Skill and the Diversification Discount}

The table reports estimated coefficients from OLS regressions for the sample of firms which report multiple business segments (diversified firms). The dependent variable is the diversification discount, measured as the natural logarithm of the ratio of the imputed market-to-book ratio to the firm's actual market-to-book ratio. The imputed market-to-book ratio is the asset-weighted average of the median market-to-book ratio among single-segment firms operating in each of the diversified firms 3-digit SIC codes. \% Assets in High Skill Ind. is the percentage of the firms assets in segments which operate in 2-digit SIC codes in which the percentage of workers with 2digit SOC codes less than 29 exceeds the median. Firm Size is the natural logarithm of assets. ROA is operating income before depreciation scaled by beginning-of-fiscal-year assets. Asset Tangibility is net property, plants, and equipment scaled by beginning-offiscal-year assets. Investment is capital expenditures. Investment and Cash are scaled by beginning-of-fiscal-year assets. Dividend Payer is an indicator vairable equal to 1 if the firm payed a positive dividend during the fiscal year. Book leverage is long term debt plus the current portion of long term debt scaled by the numerator plys common equity. Finance Companies are any firm with a business segment that has a 1-digit SIC code of 6 . The standard errors are clustered at the firm level and are reported in parentheses. *,**, and *** represent significance at $10 \%, 5 \%$, and $1 \%$ level, respectively.

Full Sample $\quad$ Full Sample $\quad$ Full Sample $\quad$ No Finance Firms

\begin{tabular}{|c|c|c|c|c|}
\hline & (1) & (2) & (3) & (4) \\
\hline \% Assets in High Skill Ind. & & $\begin{array}{l}0.0722^{* * *} \\
(0.020)\end{array}$ & $\begin{array}{l}0.073 * * * \\
(0.020)\end{array}$ & $\begin{array}{l}0.0722^{* * *} \\
(0.021)\end{array}$ \\
\hline Firm Size & & & $\begin{array}{l}-0.006 \\
(0.005)\end{array}$ & $\begin{array}{l}-0.014 \text { *** } \\
(0.005)\end{array}$ \\
\hline ROA & & & $\begin{array}{l}-0.006 \\
(0.005)\end{array}$ & $\begin{array}{l}0.006 \text { * } \\
(0.003)\end{array}$ \\
\hline Asset Tangibility & & & $\begin{array}{l}0.004^{* * *} \\
(0.001)\end{array}$ & $\begin{array}{l}0.020 \text { *** } \\
(0.006)\end{array}$ \\
\hline Investment & & & $\begin{array}{r}-0.008 \\
(0.005)\end{array}$ & $\begin{array}{l}-0.079 * * * \\
(0.025)\end{array}$ \\
\hline Cash & & & $\begin{array}{l}-0.011 * * \\
(0.005)\end{array}$ & $\begin{array}{l}-0.058 \text { *** } \\
(0.021)\end{array}$ \\
\hline Dividend Payer & & & $\begin{array}{l}-0.050 * * * \\
(0.017)\end{array}$ & $\begin{array}{l}-0.061 * * * \\
(0.018)\end{array}$ \\
\hline Book Leverage & & & $\begin{array}{c}0.009 * \\
(0.005)\end{array}$ & $\begin{array}{r}0.009 \\
(0.006)\end{array}$ \\
\hline Constant & $\begin{array}{l}0.108 \text { *** } \\
(0.008) \\
\end{array}$ & $\begin{array}{l}0.056 \text { *** } \\
(0.016)\end{array}$ & & \\
\hline Year Fixed Effects & & & Yes & Yes \\
\hline $\mathrm{R}^{2}$ & 0.000 & 0.003 & 0.013 & 0.023 \\
\hline $\mathrm{N}$ & 18,397 & 18,397 & 17,367 & 14,207 \\
\hline N Firms & 3,977 & 3,977 & 3,804 & 3,191 \\
\hline
\end{tabular}

